\title{
La dimensión mítica de la peregrinación tarasca
}

\section{Roberto Martínez González}

\section{OpenEdition}

\section{Journals}

Edición electrónica

URL: https://journals.openedition.org/jsa/11250

DOI: 10.4000/jsa. 11250

ISSN: $1957-7842$

Editor

Société des américanistes

\section{Edición impresa}

Fecha de publicación: 5 junio 2010

Paginación: 39-73

ISSN: 0037-9174

\section{Referencia electrónica}

Roberto Martínez González, «La dimensión mítica de la peregrinación tarasca», Journal de la Société des américanistes [En línea], 96-1 | 2010, Publicado el 10 diciembre 2014, consultado el 02 septiembre 2022. URL: http://journals.openedition. org/jsa/11250 ; DOI: https://doi.org/10.4000/jsa.11250 


\title{
LA DIMENSIÓN MÍTICA DE LA PEREGRINACIÓN TARASCA
}

\author{
Roberto MARTÍNEZ GONZÁLEZ *
}

En el mito fundador de la Relación de Michoacán, la confrontación y alianza entre cazadores masculinos y solares y agricultores-pescadores, femeninos y acuáticotelúricos representa la unión de principios opuestos y complementarios análogos a los que participan en la constitución del ser humano. Considerando que la deidad y el pueblo se representan mutuamente, el desplazamiento de los chichimecas en dirección norte-sur, comparable al aparente movimiento estacional del sol en el horizonte, simboliza tanto los orígenes del verdaderamente tarasco como el cambio en las estrategias económicas a través del ciclo anual. En el plano sociológico, la unión de los opuestos origina un estado dividido en tres capitales. En lo corporal, los componentes fríos y calientes dan vitalidad a un tercer elemento que funge como centro regulador. Son los mismos principios lógicos por los que cuerpo, sociedad y cosmos se refieren uno a otro a través de metáforas. [Palabras claves: Mexico, p'urhépecha, tarasco, mito, cosmovisión, noción de persona.]

La dimension mythique de la migration tarasque. Dans le mythe fondateur de la Relación de Michoacán, la confrontation et l'alliance entre les chasseurs masculins et solaires, d'une part, les pêcheurs-agriculteurs féminins, aquatiques et telluriques, d'autre part, renvoient à l'union de principes opposés et complémentaires analogues à ceux qui participent à la constitution de l'être humain. Considérant que la divinité et le peuple se représentent mutuellement, le déplacement des Chichimèques du nord au sud, comparable à l'apparent mouvement saisonnier du soleil sur l'horizon, symbolise à la fois les origines du vrai Tarasque et le changement de stratégies économiques à travers le cycle annuel. Sur le plan sociologique, l'union des opposés est à l'origine d'un État divisé en trois capitales. Sur le plan corporel, les composants chaud et froid donnent vie à un élément qui agit en tant que centre régulateur. C'est par les mêmes principes logiques que le corps, le cosmos et la société se référent les uns aux autres à travers des métaphores. [Mots-clés: Mexique, P'urhépecha, Tarasque, mythe, cosmovision, notion de personne.]

The mythic dimension of the Tarascan migration. In the foundation myth described in the Relación de Michoacán, the alliance and confrontation between male solar

\footnotetext{
- Investigador del Instituto de investigaciones históricas de la UNAM, circuito Mario de la Cueva s/n, zona cultural, 04510, Ciudad universitaria, Coyoacán, México [nahualogia@yahoo.com.mx].
}

Journal de la Société des Américanistes, 2010, 96-1, pp. 39-73. O Société des Américanistes. 
hunters and female aquatic-telluric, fisher-farmers represent the union of opposites but complementary principles, analogous to those participating in the set up of the human being. Considering that the deity and the people are mutually represented, the displacement of the Chichimecs in the north-south sense is comparable to the apparent seasonally movement of the sun - their god - in the horizon, and symbolizes at the same time the origins of the real Tarascan and a change in the economic strategies during the annual cycle. In the sociological sphere, the union of the opposites originates a state divided into three capitals. In the corporal plan, the cold and hot components of the body vitalize a third entity who acts as a regulator center. It's by the same logical principles that the body and the society metaphorically refer each other. [Key words: Mexico, P'urhépecha, Tarasc, myth, word view, notion of person.]

Una historia puede estar dotada de una dimensión mítica y no por ello ser falsa. El carácter de mito deriva del modo en que un evento es narrado; formando oposiciones entre elementos fundadores de la cosmovisión y enmascarando lo evidente a través de símbolos. Obviamente, ello no significa que todos los mitos se basen en eventos estrictamente verídicos, sino tan sólo que tanto el mito refleja costumbres y cualidades reales, como la historia nos presenta paisajes, personajes y eventos que nos remiten a un complejo mundo simbólico.

A grandes rasgos, el texto que aquí analizaremos, la segunda parte de la Relación de Michoacán (RM) - o Relación de las creencias y ritos y población y gobierno de los indios de la Provincia de Michoacán-, habla de un grupo de aguerridos cazadores (los chichimecas-uacúsechas) que, guiados por su deidad patrona (Curicaueri), abandona la región de Zacapu para instalarse en la ribera del Lago de Pátzcuaro y, tras someter a los tarascos lugareños, conquista prácticamente todo el actual Estado de Michoacán. La dimensión mítica del relato se aprecia en varios aspectos: en primer lugar, se trata de una narración a posteriori que tiene lugar en una ocasión ritual. Segundo, existen detalles tan exagerados que no pueden constituir más que metáforas de las cualidades que se pretende describir. Tercero, algunos de los eventos de la peregrinación y conquista uacúsechas se encuentran en relatos migratorios de otros pueblos mesoamericanos. Y, cuarto, las cualidades de los personajes están demasiado polarizadas como para ser reales. Y es justamente a través del juego de oposiciones que se va tejiendo a lo largo del texto que pretendemos desentrañar los principios lógicos del mito; la unión de opuestos complementarios que da lugar al hombre actual, a un sistema político tripartita concentrado en una ciudad principal y la migración norte-sur asociada a la alternancia de los ciclos estacionales y el cambio en las estrategias económicas.

Gracias a la comparación de estos resultados con lo que se observa en los mitos y rituales contemporáneos mostraremos que, de algún modo, la estructura del relato fundacional de la Relación tiene resonancia en la imagen del cuerpo y el cosmos en general. 


\section{Mito o historia: la SEgunda parte de la Relación de MichoacÁN}

A pesar de que algunos investigadores han encontrado interesantes relaciones entre los p'urhépecha y algunos pueblos del norte de Sudamérica y el suroeste de Norteamérica, la verdad es que su origen exacto todavía nos es inaccesible ${ }^{1}$. Sabemos por las fuentes documentales que, desde el siglo XIII, en la región de la Sierra Central michoacana, se encontraban asentados algunos grupos de lengua tarasca; sin embargo, se desconoce su extensión y se ignora desde cuando (López Austin 1981, p. 17).

Recientes investigaciones arqueológicas en lo que fue la cuenca lacustre de Zacapu demuestran una larga trayectoria de la cultura p'urhépecha en la región. De acuerdo con Carot (s. d., pp. 1-59), dicho grupo tiene sus antecedentes más profundos en Chupícuaro y se extiende, a través de las tradiciones Queréndaro y Loma Alta, en el periodo clásico. Hacia el 550 dC, la tradición p'urhépecha debió sufrir un breve periodo de decadencia causado por el impacto indirecto de la caída de Teotihuacan; es en este momento que algunos pobladores dejarían la región para migrar hacia el norte. Se supone un cierto reavivamiento cultural tarasco hacia los siglos VIII y IX, cuando los que habían partido emprenden el regreso hacia la zona lacustre ${ }^{2}$. Estos nuevos p'urhépecha habrían importado toda una cultura guerrera ajena a los habitantes de la zona, pero afín a la de los chalchihuiteños y los más tardíos toltecas; se rastrea a dichos migrantes por la cuenca del Río Lerma, Zacapu y la zona del Lago de Pátzcuaro ${ }^{3}$.

Obviamente, es aquí donde deberían encadenarse las observaciones arqueológicas con lo relatado por la segunda parte de la Relación de Michoacán ${ }^{4}$.

En lo que se refiere al carácter de dicho relato, encontramos cuatro principales posiciones: en primer lugar, tendríamos a quienes, como Ruiz (1979), Miranda (in Alcalá 1980, p. XXXVII), Pollard (1994, p. 221) y Haskell (2008) ${ }^{5}$, consideran que todo lo narrado tiene un carácter mítico y no posee ninguna relación con la realidad histórica. En segundo se ubican los que, siguiendo a León (1906), Kirchhoff (1956) y, más recientemente, Carot (s. d.) atribuyen a la segunda parte un valor esencialmente histórico; e incluso destacan la admirable memoria de tal pueblo al recordar con exactitud eventos que se remontan a trece generaciones de gobernantes. En tercer sitio, Michelet (1998, p. 51) y López Austin (1981, p. 26), en un punto intermedio entre los anteriores, argumentan que el escrito en cuestión reproduce la visión oficial de la toma de poder en el corazón de Michoacán por los ancestros del grupo dirigente al momento del contacto con los españoles; en otras palabras, admiten el valor histórico del documento pero le adjudican una cierta parcialidad. Por último, encontramos a quienes, como Le Clézio (1988, pp. 145-146), Michelet (1989), Franco Mendoza (2000a; 2000b) y Faugère (2008, p. 114) consideran que, sin negarse el valor histórico de la fuente, existe a la vez una dimensión mítica del discurso ${ }^{6}$. 
Nosotros nos ubicamos en esta última perspectiva; pues, sostenemos que se trata de una historia constituida en parte por eventos reales pero con la finalidad principal de resolver oposiciones fundamentales de la concepción indígena del mundo ${ }^{7}$.

A pesar de su etimología, pensamos que un mito no necesariamente es una mentira sino que, como lo ha mostrado ampliamente López Austin (1989), en Mesoamérica, la idea del hombre-dios hace posible que los eventos reales, sobre todo vistos en retrospectiva, adopten las lógicas de los relatos creacionistas y, con ello, se renueven los principios básicos del sistema de pensamiento. Más allá de su veracidad o falsedad, el mito es una estructura del lenguaje que tiene por función solucionar oposiciones fundamentales en la cosmovisión de un grupo y se caracteriza por construirse bajo una doble articulación. En otras palabras, no es sólo el contenido lo que define al mito, sino sobre todo la forma en que éste se relata; constituyendo oposiciones binarias y enmascarando lo que sería una verdad evidente bajo el complejo lenguaje de los símbolos (Barthes 1980, p. 199; LéviStrauss 1955).

La migración y conquista de los uacúsechas, tal como nos es presentada por la Relación (1980, pp. 17-19), es una historia que, además de pasar de lo oral a lo escrito, se narra en retrospectiva y en un evento ritual equata consquaro, la « fiesta de las flechas ". Los sucesos de la antigüedad adquieren una nueva carga simbólica a partir de los usos sociopolíticos del relato y los eventos « originales » se vuelven portadores de un sentido profundamente anclado en los principios fundadores de la cosmogonía indígena. Así pues, a lo largo del presente trabajo, se pretende mostrar el modo en que el relato de la migración y conquista reconstruye y actualiza la forma en que el pueblo tarasco se concebía a sí mismo en su relación con el entorno y con la propia imagen del ser humano.

\section{LA DIMENSIÓN Mítica DE LA MIGRACIÓN CHICHIMECA Y LA CONQUISTA DE MichoacÁN}

La segunda parte de la Relación es, en definitiva, la sección más extensa y detallada de nuestra fuente - tanto en el texto escrito como en las imágenes. Aunque se encuentra plagada de nombres y detalles asombrosos, consideramos que esta puede, de manera muy burda, dividirse en tres segmentos principales.

El primero daría inicio con el encuentro entre el caudillo Hireti Ticatame y la deidad Curicaueri en Zacapu. Continuaría con la alianza entre los chichimecas y la gente de Naranjan a través del matrimonio entre Curicaueri-Ticatame y la hermana del señor local. Y concluiría con el conflicto que desata entre las partes la violación de la norma de conservar las pieles de venado para la divinidad cazadora por parte de los lugareños; dicho altercado provoca tanto la huída de los uacúsechas como la posterior muerte de su caudillo. 
El segundo episodio es aquel que se ocupa de la etapa de peregrinación y alianza, desde la llegada de los chichimecas a Pátzcuaro hasta el matrimonio entre Pauacume y la hija del pescador, y el consecuente nacimiento de Tariácuri. Es en esta misma sección que se produce la segunda revelación de las divinidades en Petatzequa y se designa a Pátzcuaro como asiento de los templos.

El tercer apartado, el más amplio de todos, comprende la etapa de conflicto. Y constituye una multitud de pequeños relatos sobre los diversos engaños y triquiñuelas que ejecutan los lugareños en contra de los recién llegados. Dichas ofensas desembocan en una tercera revelación divina - esta vez en relación a Hiripan y Tangaxoan -, la conquista de la región del Lago y la resultante consolidación de tres capitales - Ihuatzio, Pátzcuaro y Tzintzunzan. Al final de esta parte, y de manera muy abreviada, se cuenta el modo en que lugareños y chichimecas terminan por aliarse para dominar el resto de Michoacán y, por último, la forma en que el poder político y las deidades patronas se concentran en una sola capital, Tzintzuntzan-Michoacán.

Lo primero que podemos notar al estudiar las migraciones p'urhépecha es que muchos de sus pasajes se muestran extraordinariamente estereotipados y con características tan exageradas que rayan en lo inverosímil. Entendemos, por ejemplo, que el arco y la flecha puedan ser considerados como armas típicamente chichimecas - tal como lo sostiene Carot (s. d., p. 36) -, pero nos resulta absolutamente imposible que los antiguos habitantes de Zacapu no dispusieran más que unas varas para defenderse (Relación de Michoacán 1980, p. 28) ${ }^{8}$. Los chichimecas son presentados como cazadores y los lugareños como pescadoresagricultores; sin embargo, resulta obvio que se trata de una metáfora cuando, en el momento de la alianza con los isleños, se dice que el poblador local no conoce el conejo y los cazadores nómadas - que provienen de una región lacustre nunca han comido pescado (Relación de Michoacán 2000, p. 354) ${ }^{9}$. Lo mismo sucede con el « descubrimiento » del oro, la plata y las plumas preciosas, por parte de los uacúsechas, al momento de la conquista del Lago; pues no resulta creíble su desconocimiento cuando, simultáneamente, se cita que, a Curicaueri, sus padres le habían ordenado que se apoderara de ellos: «- ¿Cómo conocemos esto? como quien dice no lo conocemos ni sabemos qué es esto. Es lo que la gente lleva huyendo yan [sic] lo han traído a Curicaueri. Esto es lo que le dijeron sus padres en el cielo que él quitase a todos, todas las joyas, y que las tuviese él sólo » (Relación de Michoacán 1980, pp. 196-197). A todo esto se puede añadir que, como señala Michelet (1989, p. 107), « el tiempo en la narración se aleja completamente de la duración real ».

Por otro lado, si comparamos los relatos p'urhépecha con las narraciones de migraciones de otras partes de Mesoamérica podemos encontrar coincidencias que, definitivamente, no se deben al azar, sino al hecho de compartir, al menos parcialmente, una visión del mundo (ver tabla). Es notable, para empezar, que tanto en los tarascos como en los quichés y los toltecas-chichimecas se encuentren 
cacerías de venados al origen de conflictos bélicos ${ }^{10}$. Es probablemente, en relación con la misma actividad cinegética que los caudillos tienen deidades asociadas al ciervo; Tojil e Itzpapalotl toman la forma de venados, mientras que Curicaueri es envuelto en pieles de dicho animal (Popol Vuh 1971, p. 193; Leyenda de los soles 1945, p. 123; Relación de Michoacán 1980, p. 24) ${ }^{11}$. También vemos que, en todos los casos, los lugareños ofrecen mujeres al pueblo migrante para tratar de apaciguar su poderío. En la Relación de Michoacán (1980, p. 21), cuando se narra el encuentro de Hireti Ticatame con Curicaueri, se nos dice que, al recibir la noticia de la presencia de un nuevo dios en la comarca, lo primero que hizo Ziran Zirancamaro fue ofrecerle una hermana; poco después de su matrimonio, Ticatame es muerto por sus cuñados. Con Tariácuri pasa más o menos igual, salvo que aquí son sumamente explícitas las intenciones de los autóctonos: «- Tariácuri tiene a Curicaueri que es gran dios. ¿No sería bueno que le llevasen vuestra hermana [... Se recomienda a la mujer:] - No te apartes de tu marido mas está de continuo con él y, trátete como quisiere, no le digas nada. Y placerá a los dioses que tuvieses un hijo de él y así le quitaremos a Curicaueri » (ibid., p. 86) ${ }^{12}$. Habiéndose dicho que los ancestros quichés « sólo tienen el poder y la gloria porque nunca ven mujeres", los señores de las parcialidades les envían tres vírgenes desnudas con la intención de que sean violadas por ellos (Título de Totonicapán 1983, p. 180 fol. 12v; Popol Vuh 1971, p. 197). En el caso de los cakchiqueles, se dice mucho más explícitamente que las parcialidades ofrecerían mujeres a Cay noj y Cay batz para, haciéndolos sus yernos, recuperar lo que les habían quitado (Memorial de Tecpan-Atitlan 1934, p. 221). Por último, en el caso tolteca-chichimeca, tenemos que, después de haber realizado grandes conquistas, Mixcoatl se encuentra, en Huitznahuac, con una mujer desnuda llamada Chimalma; se acuesta con ella y, en seguida, sus hermanos mimixcoa deciden asesinarlo y enterrar su cuerpo en la arena (Leyenda de los soles 1945, p. 124). De sobra está decir que, incluso en el caso maya, se presenta al pueblo viajero como rústico y salvaje; se dice que carecen de un hogar, que visten con pieles sin curtir, cortezas de árbol o heno, que no conocen el fuego y faltan de la más mínima sofisticación (Titulo de Pedro Velasco 1989, p. 175; Anales de Cuauhtitlan 1945, p. 4). Tanto en el caso mexica como en el p'urhépecha, el lugar de llegada es un poco un reflejo o un paralelo del de salida; Aztlan y México son islotes en medio de un lago, Zacapu y Pátzcuaro son poblados al borde del agua - en ambos sitios se revela la deidad y, dicho sea de paso, el nombre completo de Pátzcuaro también contiene la palabra Zacapu, Cacapu hamúcutin Pázcuaro (Relación de Michoacán 2008, p. 72v). Las deidades patronas de nahuas, tarascos y quichés - Huitzilopochtli, Curicaueri y Tojil - se asocian a lo ígneo y solar ${ }^{13}$. Y, en los tres casos, el resultado de la historia es la formación de reinos tripartitas: Tenochtitlan, Texcoco y Tlacopan; Pátzcuaro, Tzintzuntzan e Ihuatzio; y los Cawekib, los Nijaib y los Ajaw Q'uiché. Un último aspecto a resaltar es la borrachera de dioses o gobernantes en los relatos sobre la caída de los grandes 
imperios; Quetzalcoatl se embriaga antes de fin de Tula, Tezcatlipoca aparece ebrio para anunciar la destrucción de Tenochtitlan (Graulich 1997) y « el cazonçi llamado Zuangua, estaba a la sazón cerca de su casa, en un lugar llamado Arátaquaro, y estaba borracho » cuando los sacerdotes de Cuerauaperi fueron a anunciarle el presagio de la llegada de los españoles (Relación de Michoacán 2008, fol. 38v).

Un segundo aspecto a resaltar en la Relación es que las cualidades de los distintos grupos se encuentran absolutamente polarizadas ${ }^{14}$.

Aunque el relato se esfuerza por distinguir entre las localidades, notamos que, desde el inicio, se establece la oposición entre lugareños - ya sean los del lago de Zacapu o el de Pátzcuaro - y chichimecas. Las cualidades más destacadas en los lugareños son: el ser viejos (Relación de Michoacán 1980, p. 178) ${ }^{15}$, beber alcohol (ibid., pp. 32, 38, 63, 68, 76, 87, 88, 90, 91, 107, 120, 131, 179-180, 185), pescar y sembrar (ibid., pp. 26,32), hablar una lengua « corrupta y serrana » (ibid., pp. 27, 35), ser ricos y poderosos (ibid., pp. 44, 97, 132), lujuriosos y adúlteros (ibid., pp. $30,78,82,91,96,137,146)$ y valerse de conjuros o adivinaciones para derrotar a sus enemigos (ibid., pp. 112, 185) ${ }^{16}$.

Entre las características que mayormente se citan para los chichimecas se encuentran: traen leña para sus deidades y se autosacrifican (Relación de Michoacán 1980, pp. 21, 60, 92, 93, 121-124, 157, 160), dan de comer a los visitantes y ofrecen mantas (ibid., p. 22), no olvidan las injurias (ibid., pp. 24, 47, $49,53,60$ ), se la pasan haciendo flechas (ibid., pp. 67, 151, 157), son castos (ibid., p. 106), no beben (ibid., pp. 89, 95-96) ${ }^{17}$, son buenos cazadores (ibid., p. 103) y jóvenes y pobres (ibid., pp. 121-124, 160, 196-197) ${ }^{18}$. Así pues, el ser considerado como chichimeca o autóctono parece más una cuestión comportamental que algo relacionado a la filiación o un modo de vida específico - chichimeca y lugareño serían así lo que Haskell (2008, p. 234) denomina « categorías elementales [...] concepciones abstractas y fundamentales representadas por personas ». Es notable, por ejemplo, que Hiquingaje, sacrificador y penitente pero hijo y nieto de lugareñas, es considerado como chichimeca a pesar de que no se dedique exclusivamente a la caza y lleve una vida plenamente sedentaria (Relación de Michoacán 1980, p. 169). En contraparte, su medio hermano mayor Curatame, que es rico, poderoso, ebrio y lujurioso, es citado como un «advenedizo » habitante de Coringuaro (ibid, p. 133). El caso de Tariácuri es particularmente notable; pues, mientras se le llama chichimeca durante toda su juventud casta y guerrera (Relación de Michoacán 2008, pp. 79v, 93v), ya que envejece $\mathrm{y}$ vive rodeado de sus mujeres, comienza a recordarse su origen isleño (ibid. 1980 , p. 136) ${ }^{19}$.

Un último punto a subrayar es el tipo de relaciones simbólicas que se establecen entre el dios patrono, el gobernante y su pueblo. Según hemos dicho en otra ocasión (Martínez González 2008), entre las múltiples deidades que tenían los p'urhépecha, existía una que supuestamente se encontraba más íntimamente 
ligada a una colectividad - ya sea una ciudad, un barrio o un grupo étnico-social específico. Independientemente de sus atributos particulares y la posición que ocupara en el cosmos, esta divinidad se identifica con un conjunto de individuos al que protege e infunde sus principales cualidades. En las metáforas, el origen de un pueblo coincide con el origen de la deidad mientras que su destrucción o sujeción concuerda con la pérdida del dios patrono. Aparentemente, la relación que establece el pueblo con su deidad tutelar es producida bajo el modelo de la filiación ${ }^{20}$. El vínculo entre divinidad y población es tan fuerte que incluso, se conoce el caso de que, habiendo sido robado el dios, éste decide enfermar a sus captores a fin de que pueda ser recuperado por los suyos (Relación de Michoacán 1980 , p. 29). En caso de guerra, los dioses fungen como estandartes que acompañan y socorren a sus fieles (ibid., pp. 20, 186, 239). Otras veces, el dios protector puede manifestarse en manera zoomorfa para guiar a su pueblo o revelarles conocimientos ocultos (Códice Plancarte 1959, p. 9). Al mismo tiempo, no sólo parece existir una estrecha relación entre la deidad y su pueblo sino también entre el dios y el territorio en que se asienta el grupo; esto se ve en el hecho de que todo asentamiento debía contener una representación de la divinidad en cuestión (Relación de Michoacán 1980, p. 110). Incluso, se cree que son los propios dioses quienes hacen posible la fortificación del territorio (Beaumont 1932, II, p. 6).

Sin embargo, entre todos los individuos, es definitivamente el señor quien se encuentra en mayor proximidad a la deidad; pues, además de decirse que el cazonci está en lugar del dios (Relación de Michoacán 1980, pp. 224, 244, 258), las Relaciones de Tiripitio y Tuzantla (en Relaciones geográficas del siglo XVI 1987, pp. 157, 348) dejan en claro que, cuando menos, algunos dirigentes tenían la facultad de dialogar con las divinidades. Incluso se supone que sólo a través del contacto directo con la sobrenaturaleza es válido adquirir el poder señorial (Relación de Michoacán 1980, pp. 174-176, 379) ${ }^{21}$. Aun muerto, el señor es tratado como una divinidad pues, más allá de las suntuosas exequias que usualmente se hacen a los gobernantes, se nos especifica que, después de su cremación, el bulto era portado por uno de los cargadores de los dioses y sepultado al pie del templo principal (ibid., pp. 277-278). Siendo que la divinidad tutelar es igualmente un emblema de la nación, entre las obligaciones principales del irecha figuraban tanto la administración de su culto como la expansión territorial a través de la actividad bélica (ibid., pp. 259, 284-285). Sin embargo, la encarnación del patrono también tiene una manifestación material; misma que se concretiza en la custodia del bulto sagrado por el gobernante (ibid., p. 140). Así, aunque el irecha nunca llega a confundirse con la divinidad, es claro que este actúa como su representante, lugarteniente o emblema principal ${ }^{22}$. De este modo, vemos que, así como la deidad patrona se construye como una proyección ideal de la comunidad, el gobernante se presenta como una representación en la tierra de la divinidad. Esto significa que las cualidades del grupo, la deidad y el señor no serían más que prolongaciones unas de otras; y que, aquello que se dice de un 
irecha puede muy bien extenderse a la colectividad. Esto último resulta de particular relevancia para elcasoestudiado; ya quela Relación casino habla delosgrupos o individuos comunes, sino que, por el contrario, todos los conflictos y alianzas son representados en términos de negociaciones entre clases gobernantes ${ }^{23}$.

En resumen, podemos resaltar tres aspectos esenciales para la lectura del relato que nos ocupa.

1) El reconocimiento de una dimensión mítica que, al menos, en parte se vincula con otras tradiciones mesoamericanas.

2) La oposición entre lugareños ricos, lujuriosos, alcohólicos... y migrantes cazadores, pobres, castos...

3) La relación de mutua representación entre la deidad patrona, el caudillo y el pueblo. De tal suerte que, como ya lo había notado Michelet (1989, p. 109), cuando interpretemos el relato, podremos considerar que aquello que afecta y concierne al dios o al gobernante se proyecta sobre el grupo en general ${ }^{24}$.

Así, en relación con las cualidades de los dioses patronos, comprendemos mejor las características que tipifican a los pueblos. Los uacúsechas como pueblo del sol - desde tiempos de Seler (2000, pp. 217-218) y Corona Núñez (1993, p. 373) se reconoce a Curicaueri como una divinidad solar - se niegan a beber alcohol en múltiples ocasiones; pues, de hacerlo, tenderían a identificarse con Tares Upeme, el dios al que se expulsa del cielo por borracho (Relación de Michoacán 2008, p. 111v). El carácter de cazadores-guerreros, castos y orgullosos de los uacúsechas - comparable al de los mexicas -, está estrechamente unido al destino de su divinidad; a quien « los dioses del cielo le dijeron cómo había de ser rey y que había de conquistar toda la tierra » (ibid., fol. 6). En el Códice Plancarte (1959, p. 9), es el águila quien guía a los chichimecas en su peregrinación y " Ticatame como quien era águila, uacusecha, enojose y sacó una flecha de su aljaba, armó su arco y tirósela a un cuñado suyo » (Relación de Michoacán 1980, p. 24). Tampoco es por azar que sea el pueblo de « el sale haciendo fuego » $\mathrm{o}$ « el fuego que sale ardiendo » quien se dedique a hacer hogueras a sus dioses ${ }^{25}$.

Como Xaratanga es la diosa que trae los productos agrícolas a la tierra, sus seguidores son pensados como ricos y poderosos (Relación de Michoacán 1980, p. 31$)^{26}$. La ebriedad de su pueblo se vincula a su poder para controlar los efectos del pulque y, como diosa del Lago, tiene la capacidad de ofrecer u ocultar a los peces (ibid., pp. 34, 63) ${ }^{27}$. Evidentemente, las cualidades reproductivas de los recursos acuíferos y agrícolas, se asocian al incontenible deseo sexual de los lugareños. Prueba de ello es la historia de Mahuina, la cuñada de Tariácuri, quien, en un pabellón, se vestía como la diosa lacustre y hacía « que le llamasen los mancebos hermosos que pasaban por el mercado y todo el día se juntaba con ellos » (Relación de Michoacán 2008, fol. 113). El deseo sexual se asocia a lo femenino - la Relación de Michoacán (ibid., fol. 86) nos dice explícitamente que las señoras «son incontinentes "; lo cual, asociado al pueblo autóctono, muy 
probablemente alude a la disposición de la tierra de ser fecundada y dar vida - Xaratanga significa «la que hace que otro tenga placer, gusto, contento » (Monzón 2005, p. 152). Es también relevante que sean los lugareños quienes se valen de procedimientos sobrenaturales para combatir a sus enemigos pues, hoy en día, son mayoritariamente las mujeres quienes, como sikuámecha, se dedican a la gestión del infortunio - cura, adivinación, brujería, etc. (Velásquez Gallardo 2000, pp. 125-126; Gallardo Ruiz 2005, p. 19).

De este modo, la confrontación entre chichimecas y lugareños no se reduciría a la oposición entre cazadores y pescadores-agricultores ${ }^{28}$, sino que, mucho más ampliamente, concerniría lo celeste y lo acuático-telúrico, lo masculino y lo femenino, lo móvil y lo estático, lo fecundador y lo fecundado... ${ }^{29}$.

\section{Peregrinación, alianza y cambio estacional en Michoacán}

Una vez considerado que el gobernante, el pueblo y la divinidad se representan mutuamente y aclarada la identidad de Curicaueri como helio-astro, resulta mucho más fácil comprender el sentido de la migración chichimeca.

El pueblo, como entidad autónoma, y la deidad surgen en el momento mismo en que se produce el encuentro con el caudillo en la cima del cerro: « Empezó su señorío donde llegó al monte llamado Uiruguarapexo, monte cerca del pueblo de Zacapo Tacanedan » (Relación de Michoacán 1980, p. 20) ${ }^{30}$. De ahí, el sol y su pueblo, se desplazan hacia el sur hasta llegar a Pátzcuaro, lugar en que se produce la segunda revelación divina (ibid., p. 27) y los chichimecas deciden asentarse, aliarse con los lugareños y pasar de la caza a la pesca y la agricultura: cuando los chichimecas viven en Uayameo - a mitad de camino - de manera sedentaria, no se menciona más actividad económica que la caza; mientras que, aunque nunca se especifica el momento en que se adopta la agricultura, es claro que ya en el Lago el pueblo migrante cuenta con milpas (ibid., pp. $30,80,111,114,153)^{31}$.

Más allá de las implicaciones políticas, que después analizaremos, encontramos que la deidad solar se presenta por primera vez en un cerro norteño y, por segunda, en unos peñascos al sur. Como sabemos, hacia el Trópico de Cáncer, el movimiento aparente del sol implica un desplazamiento en el horizonte de $23^{\circ}$ al norte y $23^{\circ}$ al sur según las épocas del año. En los equinoccios de primavera y otoño el sol se encuentra en el punto medio; mientras que en el verano alcanza el límite norte y en invierno el límite sur (ver Broda 1991; 2001). Si esto concordara con las migraciones de nuestra historia, tendríamos que en el verano - momento previo a la cosecha en el que, por lo común, escasean las reservas agrícolas pero abundan los recursos silvestres - nuestros protagonistas viven en la pobreza y se dedican exclusivamente a la cacería. Mientras que en el invierno - época de abundancia justo después de la cosecha - comienza la vida sedentaria y da inicio el ascenso del señorío. El norte-verano es el punto en que el día es más largo, 
razón por la cual, durante la migración al sur, el periodo luminoso habría ido decreciendo y la temperatura descendiendo. El movimiento, iniciado tras la alianza con Ziran Zirancamaro, un personaje en cuyo nombre figura la raíz zira« frío », se detiene en Pátzcuaro, un sitio que según Ajofrín (1986, p. 96), se encuentra asociado a la muerte: « Llámase Pátzcuaro, que en lengua tarasca es lo mismo que lugar de luto ». Es como si, en el desplazamiento chichimeca, el astro solar hubiera ido muriendo hasta llegar al punto de su renacimiento - un lugar simétrico al de su partida. Desde ahí inicia la conquista de la tierra por parte de sus seguidores, justo cuando la temperatura vuelve a aumentar y empieza a haber más luz - son las fuerzas solares que vencen a las terrestres ${ }^{32}$.

En un trabajo recientemente publicado en esta misma revista, Faugère (2008, pp. 125-126) presenta una interpretación de un famoso mito tarasco que ayudaría a fortalecer nuestra propuesta. De acuerdo con el relato, Cupanzieeri fue a Jacona a jugar a la pelota con Achuri Hiripe y, tras haber perdido la partida, muere sacrificado a manos de su adversario dejando a su mujer preñada. Años más tarde, su hijo póstumo, Sirahtatahperi sale de cacería y se encuentra con una iguana que le dice que, si no la mata, le revelará un secreto; que su verdadero padre no es el que lo crió sino aquel que yace muerto en Jacona. El joven toma venganza, desentierra a su padre para llevarlo a casa y, cuando se detiene para matar unos pájaros deja el cadáver en el suelo y éste se convierte en venado. Cupanzieeri significa "el sol tomado por los cabellos» o "despojado de sus cabellos », Jacona es la " casa de la tarde », Achuri Hiripe, " la noche que se apresura ", " los innumerables de la noche » o "el dominador de la noche » y Sirahtatahperi « del linaje de su padre ». Si reintroducimos estos significados en el texto, podemos ver que el mito estaría hablando de « el sol » que va a la « casa de la tarde » a morir en manos de « la noche que se apresura » y tras ser enterrado termina por convertirse en venado; de tal suerte que dicho cérvido representaría al sol después de su muerte y resurrección - en otras palabras, el sol naciente. «Sabemos, en fin, que durante la fiesta de Cuingo, se preparaban panes de vegetales en forma de venados [...] La fiesta de Cuingo corresponde a la de Tlacaxipehualiztli mexica, es decir que corresponde a la fiesta del rejuvenecimiento del sol » (ibid.).

Ahora, si regresamos a nuestro relato migratorio, podemos ver que a Curicaueri, que también encarna al sol, se le envuelve con pieles de ciervo al inicio de la historia, justo después de que su aparición, cuando los chichimecas se encuentran al norte, cuando inicia su travesía y cuando el día es más largo; es decir, cuando actúa como sol naciente.

Es justo en Pátzcuaro donde se da la primera unión de los contrarios, la conjunción entre los lugareños y los migrantes; dicha fusión tiene su paralelo sobrenatural en el momento posterior en que Curicaueri - el sol - y Xaratanga - el lago-tierra - se unen en Tzintzuntzan (Relación de Michoacán 1980, p. 213). El producto de la alianza humana es Tariácuri quien, además de ser el primer 
unificador tarasco, se encuentra asociado al viento - su nombre significa « viento de fuego » o «el que se alimenta de viento » (Corona Núñez 1948, p. 141) -, un elemento que, obviamente, vincula al cielo con la tierra y el agua. Esta misma conjunción es expuesta al momento en que se unifica Michoacán y se reparte el poder entre tres primos - Hiripan, Tangaxoan e Hiquingaje - a cargo de tres capitales; Pátzcuaro con Curicaueri, Tzintzuntzan-Michoacán con Xaratanga e Ihuatzio-Coyoacan con el Coyote. No disponemos de muchos datos sobre el simbolismo de este cánido, mas, dada la similitud entre su aullido y el zumbido del viento, hoy en día se le atribuye una función mediadora semejante a la de los fenómenos eólicos (Gallardo Ruiz 2008). Tzintzunzan-Michoacán es el antiguo pueblo de los lugareños, Pátzcuaro es fundado por los chichimecas y, curiosamente, Ihuatzio no figura en la Relación sino hasta el momento en que se produce la unificación. ¿Será que dicho asentamiento se asocia a la imagen de síntesis? El único elemento de que disponemos para apoyar esta hipótesis es el hecho de que, al unificarse el señorío tarasco, los tres primos deciden poner todo el tesoro en dicha ciudad y se explica que " allí mirarán los dioses este tesoro » (Relación de Michoacán 2008, p. 132) ${ }^{33}$.

Aquí podemos hacer un paréntesis para señalar que, aparentemente, la deidad del coyote no constituía un caso extraordinario, sino que, por el contrario, los tres « diablos » que revelaban secretos a Vacuxen se encontraban igualmente asociados a tres animales vinculados a tres ciudades: « estos eran sierpes, lobos, águilas, a uno de ellos era al que idolatran y otro en Uándaro, y otro en Curiquaycharo y otro en Patzuendo " (Códice Plancarte 1959, p. 14). Considerando que Curicaueri se presentaba sobre la tierra como águila y que Xaratanga transformó a sus sacerdotes transgresores en serpientes, es muy posible que el lobo o coyote no fuera más que una suerte de alter ego zoomorfo de una tercera divinidad cuyo nombre no nos es revelado (Relación de Michoacán 2008, fol. 36v, p. 68).

Existen dos grandes altercados con las familias políticas de los uacúsechas que dan lugar a los eventos más importantes del relato; la salida de Zacapu y la conquista del Lago. Después de la primera ruptura con los autóctonos la mujer de Ticatame se lleva consigo a Uazoriquare, el dios del monte que « da de comer a los hombres " y lo fusiona con Curicaueri (Relación de Michoacán 1980, p. 26); en la segunda, la mujer de Tariácuri trata de llevarse a la deidad patrona y regresa a su lugar de origen con todo y su hijo. Lo primero sucede después del verano-norte y llevarse al dios es un paralelo de riqueza de los recursos silvestres $-o$, tal vez las primicias; lo segundo, se da después del invierno-sur, cuando los días son más cortos y el sol corre el riesgo de " morir ».

Por lo común, agricultores y pescadores suelen presentarse con cualidades afines; entre otras cosas esto se debe a que, por su dependencia de los ciclos hídricos y la posibilidad de una vida sedentaria, la pesca lacustre se parece más a la vida campesina que a la de los cazadores. Sin embargo, contamos con eviden- 
cias de la existencia de una cierta alianza original entre estos dos grupos. Cuando los de Coringuaro - ribereños - se enteran de la mujer que el pescador ha dado a los chichimecas, se explica lo siguiente:

En Coringuaro aquí se hacen muy buenos maizales y semillas de bledos y mucho ají que se hace por los campos; aqui pudieran traer pescado que ofreciéramos a nuestro dios Urendequauecara y ellos en su tiempo llevaran mazorcas de maíz y semillas de bledos y frijoles y aji para ofrecer a su dios Acuizcatapeme. (ibid., p. 45).

Es tal vez por esta división interna que el pacto original entre chichimecas e isleños no constituye más que el primer eslabón de una serie de matrimonios encadenados que producen alianzas estratégicas y, al romperse, desembocan en conflictos.

Por otro lado, podemos advertir que, en el momento mismo de la alianza matrimonial entre el chichimeca y la hija del pescador, se establece una jerarquía a partir de la valoración diferencial de los alimentos en lo que podría haber sido un intercambio ritualizado (Michelet 1989, p. 111) ${ }^{34}$. El isleño dice sobre el conejo asado « Señor, esta es verdadera comida; no es cosa de pan, porque bien que sea buena comida, esta destos peces, mas hiede y harta luego; mas esta comida vuestra no hiede mas es comida de verdad » (Relación de Michoacán 2000 , p. 354). Una vez consolidado el reino, la caza se convertiría en la comida de los gobernantes y el pescado en la de la gente común; los chichimecas cazan y los lugareños pescan, los chichimecas son gobernantes y los lugareños sus súbditos " Hay pescado, que es la comida ordinaria de los macehuales» (Relación de Ajuchitlan, en Relaciones geográficas del siglo XVI 1987, p. 38). Esta estratificación se hace mucho más explícita, después de la conquista uacúsecha, en un pasaje en el que se advierte a los lugareños cuáles son las condiciones de la alianza.

\footnotetext{
Vosotros que decís que sois de Michoacán, ¡Cómo! ¿no sois advenedizos? ¿dónde han de venir más chichimecas? Todos fueron a conquistar las fronteras y así sois advenedizos [...] Vosotros que decís que sois de Michoacán y sois de los pueblos conquistados, que no dejaron de conquistar ningún pueblo. Y sois en incensados - que así hacían a los cautivos - y os dejamos por rellevo de nuestra boca, que no os sacrificamos ni comimos. Y mirad que prometisteis gran cosa: Que haríades las sementeras a nuestro dios Curicaueri y prometisteis el cincho y el hacha, que fue que traeriais leña para sus cues [...] y que acrecentareis sus arcos y flechas, con la ayuda que le daréis, y le defenderéis en tiempo de necesidad. (Relación de Michoacán 1980, p. 200) ${ }^{35}$
}

Al mismo tiempo, advertimos que no es sino hasta el momento del encuentro entre chichimecas y lugareños que se produce el verdadero ser humano, el tarasco tal como se le conoció al momento de la conquista. Antes de la alianza, los chichimecas sólo ofrendan venados, después del encuentro aparece el sacrificio humano ${ }^{36}$. Durante el proceso migratorio, se ofrecen pieles de venado a Curi- 
caueri, mientras que, después de asentado el reino, se le entregan mantas (Relación de Michoacán 2008, fol. 11v) ${ }^{37}$. En un principio, los lugareños carecen de armas verdaderas, después de la unión con los chichimecas adquieren arcos y flechas (Relación de Michoacán 1980, pp. 83-84). En otras palabras, no es que los gobernantes tarascos hayan sido necesariamente más uacúsechas que los sometidos sino que, como señala Graulich (1997, pp. 149-150), «a los pueblos conquistadores de Mesoamérica les gustaba presentarse como migrantes o nómadas recién llegados, con razón o sin ella. De ahí los múltiples relatos de migraciones, moldeados poco o mucho por el mito ». De hecho, cuando se hace la conquista del resto de Michoacán, el texto es claro en cuanto a que ya no son sólo chichimecas sino también isleños: «- Son valientes hombres de los nuestros y de los isleños » (ibid., p. 189). Es también notable que, cuando llegan los nahuas a pedir ayuda a los tarascos, Zuangua - el último cazonci - ya no sólo se refiere a la deidad solar como su patrona, sino a " nuestros dioses Curícaveri y Xaratanga » (ibid. 2008, fol. 40) ${ }^{38}$.

Cuando los tres primos - todos producto de matrimonios entre migrantes y lugareñas - toman el poder en el Lago, existe un proceso de retorno al estado chichimeca. Pues además de cumplir con la obligación ritual de llevar leña a los templos, se dirigen a una cueva de Michoacán - tal vez, equivalente al Chicomoztoc de los nahuas o el Siwán Tulán de los quichés (Título de Totonicapán 1983, p. 174) - y ahí se alimentan de ortigas en lugar de maíz y llevan bezotes de palo en lugar de un material precioso (Relación de Michoacán 1980, p. 160) ${ }^{39}$.

Así, independientemente del valor histórico de la narración, la Relación parece reutilizar los relatos migratorios chichimecas para hablar metafóricamente del paso del sol de la temporada húmeda a la seca. La transformación del pueblo elegido, de una vida de caza - que no se atestigua en los restos materiales a una centrada en la agricultura, describe la transición de la pobreza a la abundancia según los ciclos del cultivo de temporal. El cerro es el punto de encuentro entre el cielo y la tierra, el lugar donde se manifiesta en el horizonte la deidad solar y donde se revela al pueblo elegido al principio y fin de la peregrinación. Al igual que en las versiones mexicas (ver Graulich 1992), los lugareños representan a las fuerzas acuático-telúricas que, ofreciéndoles mujeres, intentan detener al pueblo viajero. A pesar de que el encuentro entre autóctonos y recién llegados nos es narrado como un conflicto, es gracias a su alianza que se hace posible la conquista de Michoacán; pues, es a partir de la unión de los contrarios que, como imagen de síntesis, surge el gobernante-viento que, además de unificar al señorío, simboliza el vínculo entre el cielo-sol y la tierra-lago. Es en este momento que surgen las verdaderas costumbres tarascas. Del encuentro viene la división en tres capitales con tres deidades patronas y tres estrategias económicas asociadas - Pátzcuaro-Curicaueri, Michoacán-Xaratanga e Ihuatzio-Coyote, caza, agricultura y pesca. Por último, se establece la unidad del reino y se confirma la estructura jerárquica bajo el dominio del pueblo solar y cazador. 


\section{La Ceremonia de Corpus y la reactualización del mito}

Aunque el simbolismo y la función social de la ceremonia de Corpus Christi en Cherán y en Michoacán, en general, son sumamente complejos y no es nuestra intención ahondar en ello, consideramos - siguiendo a Castilleja (2007, pp. 335362 ) - que, al menos, una parte de dicho ritual reactualiza la alianza entre chichimecas y lugareños ${ }^{40}$.

La fiesta se realiza generalmente a fines de mayo o principios de junio, cerca del solsticio de verano y en un momento muy próximo a la temporada de lluvias. Una semana antes de la ceremonia principal, los panaleros y los cazadores - un grupo de jóvenes adultos que no desempeñan este oficio de manera ordinaria - se van al cerro a cazar diversos animales y recolectar ramas, flores y, sobre todo, panales silvestres. En su salida, los jóvenes van acompañados por la imagen de san Anselmo, su santo patrono, - pues en dicha festividad se celebra a los oficios - y los cargueros del barrio respectivo; sin embargo, ninguno de ellos se interna en el monte y permanecen en las afueras del poblado. "A lo largo del recorrido, lo mismo que durante la preparación de éste, se permiten conductas que denotan desorden: gritos, aullidos [... Algunos panaleros] traen una máscara elaborada con piel de venado o de algún otro animal » (Castilleja 2007, p. 346).

Un día antes, en la víspera de Corpus, los panaleros se concentran en las casas de las autoridades (cabildos) del barrio respectivo de donde salen encabezados por los cargueros, para llegar acompañados de música y de gente del propio barrio a la capilla del Calvario, ubicada en lo alto del pueblo. Ahí esperan mientras reparten trago, bailan [...]; ahí las cargueras de santa Inés - pastorcita del ganado - ofrecen atole y tamales a los panaleros que se acercan entregando, como muestra de reciprocidad, un gran panal que carga uno de los cabildos. (Castilleja 2004, pp. 390-402)

Así, podemos ver que, al igual que en la Segunda Parte, es en el momento en que el día es más largo y el sol se encuentra en su plenitud previa al ocaso, que los jóvenes se ensalvajecen, portando máscaras de animales y asumiendo actitudes distintas de las ordinarias, para penetrar en el cerro - lugar de encuentro con lo divino - y traer a los lugareños, representados por las autoridades locales, los productos del espacio silvestre ${ }^{41}$. Tal como sucede en la Relación, la alianza se reactualiza por el intercambio de alimentos entre jóvenes "recién llegados» - que dan productos del monte - y mujeres « lugareñas »-que ofrecen productos agrícolas preparados; aquí, resalta el panal como algo en extremo precioso, pues el color de la miel es análogo al del sol.

$\mathrm{Y}$, aunque no se habla explícitamente de intercambios de mujeres o de un contrato matrimonial, existen claros indicios de una relación sexual simbolizada.

En la Sierra, el término khuípu se refiere tanto al « órgano genital de la mujer » como al " panal silvestre »; de modo que existiría cierta ambigüedad lingüística 
entre si se ofrece un panal o una vagina (Velásquez Gallardo 1978, p. 159; Gallardo Ruiz 2008). En otras comunidades, es común que se denomine cuipacurakua al palo encebado que traen del cerro e instalan los pamaleros; dicho término tiene la misma raiz que khuípu de que venimos hablando (Castilleja 2007, p. 343). En este punto, la connotación sexual del ritual se torna más que evidente, casi pornográfica: pues, son los que llegan del monte quienes traen un tronco que se erecta en medio del pueblo, se engrasa y luego se frota al momento en que distintas personas intentan treparlo. Para concluir, a los premios que se encuentran en la punta del palo se les llama " panal » (Castilleja 2004, p. 411), o lo que es lo mismo « vagina ». De modo que, así como son los panaleros quienes ofrecen a las autoridades locales un símbolo de los genitales femeninos, estos también expresan su poder fecundante al traer del cerro el elemento fálico que permite el acceso a la vagina-panal.

\section{EL Mito COMO geografía CORPORAL}

Contamos con poquísimos datos antiguos sobre la concepción del cuerpo y las entidades anímicas entre los p'urhépecha del siglo XvI.

El Diccionario grande de la Lengua de Michoacán (1991, I, pp. 33, 49) nos presenta tres términos diferentes como traducciones de "alma », "ánima » y " espíritu »: mintzita, tziperahperiquay y hiretaqua ${ }^{42}$. Aunque siempre resulta complejo saber si se trata de un concepto indígena o de una manipulación de los evangelizadores, el propio vocabulario nos da una idea del sentido de tales términos. Tzipequa aparece como " vida », « contento », « regocijo ", « alegría » y, en general, la raíz tzipe se relaciona a lo animado y la vitalidad (Diccionario grande... 1991, I, pp. 63, 106-107, 215; II, p. 824; Gilberti 1997, p. 169). Hiretaqua, traducido como " espiritual soplo », o « anhelito », suele ligarse a la respiración; aunque, en opinión del autor del Diccionario grande, "Esta rraíz, hire-, xahcape-, significa darse priesa, apresurarse, dar priesa y apresurar a otros " (Diccionario grande... 1991, I, p. 333; II, pp. 239, 240; Gilberti 1997, p. 92). Por último, mintzita, " corazón meollo », aparece asociado al aliento, la fuerza, el valor, la confianza, la angustia, el ánimo, la imaginación y la capacidad de pensamiento o raciocinio en general (Diccionario grande... 1991, I, pp. 45-46, 171, 233, 333; II, pp. 332-335). En la Relación de Michoacán (1980, pp. 245, 246; 2008, fol. $28 \mathrm{v}$, fol. 50 ) encontramos una serie de tropos - metáforas, metonimias - que tienden a asociar al " corazón » con el esfuerzo, el valor, el amor y el deseo: Se dice a los guerreros " - Paraos fuertes en vuestros corazones [...] Esforzaos vuestros corazones ». Cuando dos jóvenes habían tenido relaciones sexuales fuera del matrimonio los padres decían " - Ya han mudado entrambos sus corazones y han hablado entre sí ». Al momento de la conquista, los mexicas piden resignación a los michoacanos diciendo «- Esforzaos en vuestros corazones » ${ }^{43}$. 
De manera muy esquemática, podemos decir que, en época contemporánea, existe la creencia en tres principales entidades anímicas:

a) Mintzita, considerado como fuente primaria de vida, tanto en el hombre como en los animales, que, concentrada en el corazón, la cabeza y la sangre, infunde vigor a todo el cuerpo a través de la circulación sanguínea. Se supone que es este elemento quien viaja a La Gloria después del deceso del cuerpo y, como antes, se asocia a muchos de los procesos mentales (Gallardo Ruiz 2005, pp. 8588; Zantwijk 1974, p. 194);

b) Zuanda, un término que se traduce como «sombra » pero que, más bien parece estar ligado al aire, el aliento, el vaho, etc. ${ }^{44}$ Según Gallardo Ruiz (2005, p. 85), se trata de un elemento frío, principalmente vinculado a la cabeza, que, tras la muerte, "se disipa, se pierde o vaga en el mundo de los vivos asustándolos »;

c) Jurhiata, un componente caliente tan íntimamente ligado a la « sombra » que tiende a confundirse con ella; su significado puede ser tanto " sol » como « mollera » (Gallardo Ruiz 2008) ${ }^{45}$. Los diccionarios antiguos no parecen considerar a este elemento como una entidad anímica. Sin embargo, Gilberti (1901, p. 230) traduce « bruja que chupa sangre » por siquame huriata pitsipe, - jurhiata " sol, fontanela " y pitsipe « estar liso »; por lo que, tal vez pudiéramos pensar en un « brujo que alisa o desbasta la fontanela » o un « brujo que alisa o desbasta el calor ». Es muy posible que esta última entidad coincida con el esfuerzo de los de Tzintzunzan; una suerte de vitalidad innata, en la que el aumento o disminución de la temperatura durante la vida condiciona el estado físico y mental de la persona (Foster 1972, pp. 130-131). Tal como sucedía en el siglo xvI, en dicho sistema es el mintzita "corazón », quien ocupa el lugar central y a quien se atribuye mayor importancia.

Al menos, algunas de las cualidades personales están determinadas por la cantidad de calor o frío que se encuentre en su ser. Aunque el estado ideal está un tanto cargado hacia el polo caliente, cabe aclarar que todo exceso supone un peligro para el entorno; por ejemplo, un sujeto demasiado caliente podrá causar mal de ojo a los miembros más débiles y fríos de su comunidad (Gallardo Ruiz 2005, pp. 104-105). Al mismo tiempo, cuando una persona sufre una fuerte impresión - o un susto, en términos indígenas -, es posible que un dueño, o espíritu acuático-telúrico, decida capturar su sombra o su jurhiata y, con ello, cause la enfermedad y la muerte. Otras veces, puede pasar que un aire penetre en el cuerpo, desplace la sombra del individuo y ocasione un estado igualmente patológico (Moheno y Barthelemy 1994, p. 91) ${ }^{46}$. Incluso, es factible que sea el mintzita quien escape del organismo, produciéndose así un debilitamiento todavía más grave ${ }^{47}$. En todos estos casos, la enfermedad se encuentra asociada a un cierto desajuste entre los componentes fríos y calientes de los seres humanos. Por lo que, muchas de las medidas terapéuticas, además de buscar la recuperación del elemento perdido, se encuentran dedicadas al restablecimiento de un nuevo 
equilibrio por el consumo de comida de la misma naturaleza que el elemento faltante; se consumen alimentos calientes para combatir enfermedades frías y nutrientes fríos para enfrentar el exceso de calor (Foster 1972, p. 183; MotteFlorac 1997 , p. 187) ${ }^{48}$.

En todo caso, resulta claro que, en el mundo actual, no puede haber personas $100 \%$ calientes ni $100 \%$ frías; « ni ardiente con fiebre ni frío como un cadáver » (Motte-Florac 1997, p. 187). Además de los argumentos antes mencionados, esto muestra que tanto los chichimecas-solares-masculinos como los lugareñosacuático-telúricos-femeninos son seres de un orden diferente al presente y que no es más que a través de su encuentro que se produce el hombre real y contemporáneo.

Lo interesante es que, en nuestro relato, el juego entre componentes fríos y calientes no sucede en el cuerpo sino en el territorio.

A través de un brillante análisis filológico, Monzón (2005) establece los esbozos de una cosmogonía tarasca; lo cual, considerando la casi absoluta falta de información sobre las cualidades y funciones de la mayoría de los dioses, constituye un avance importante. El mundo es mencionado como parhaquahpeni, " la raíz parha significa "ser objeto cóncavo" ». Por lo que la autora sugiere pensar a la superficie terrestre como una especie de cuenco volteado. Esta tierra curva posee dos rumbos claramente identificados; el poniente se indica con el morfema de espacio -mu y el oriente con -hchu. " El sufijo -mu asociado aquí con el lugar por donde se mete el sol se utiliza para referir a un orificio o a una orilla [...] El sufijo - hchu, asociado con el punto por donde sale el sol, refiere a la zona inferior de un objeto o trasero ». Entre otras cosas, designa al trasero o el ano de un ser viviente.

Leemos en la Relación de Michoacán que « los dioses de la mano izquierda llamados vyranbanecha [son los] dioses de tierra caliente ». En otras palabras, puesto que tierra caliente se encuentra al sur, la mano izquierda apunta hacia el sur y la mano derecha apunta hacia el norte. Se puede entonces concebir al cuenco terrenal como el cuerpo de un ser animado acostado panza abajo con la mano izquierda hacia el sur, la mano derecha hacia el norte, el poniente - $m u$, que es el orificio por donde entra el sol, se puede ver como la boca, y el levante - $h c h u$, que es el lugar donde sale el sol, puede asociarse con el ano. Esta percepción del mundo se confirma en el siguiente pasaje de la Relación de Michoacán: " y al tercero día nos juntaremos todos y jugaremos en las espaldas de la tierra ». También la percepción del oro como excremento divino [que el sol echa de sí] apoya la traducción del morfema de espacio - $h c h u$ como ano. (Monzón 2005, pp. 139-141) ${ }^{49}$

Lo impresionante es que, tal como lo señala la propia autora (ibid.), el aspecto del mundo que se obtiene por el análisis etimológico se confirma en el reporte de fray Francisco Ramírez (1980, p. 360): 
Y, para tornar a restaurar las demás cosas, mandaron al dios del ynfierno que diese orden en eso; y concibiendo su muger, vino a parir todas las demás plantas y árboles, como están. Lo qual todo, decían, salía de las espaldas de una diosa que los dioses pusieron en la tierra, que tenía la cabeza hacia el poniente, y los pies hacia el oriente, y un brazo a septentrión, y otro a meridión; y el dios del mar la tenía de la cabeza; y la madre de los dioses de los pies; y otras dos diosas, una de un brazo y otra de otro, porque no se cayese.

Si pensamos, desde Pátzcuaro, que Cuerauaperi, la madre de los dioses que detenía los pies de la Tierra, se ubicaba en las proximidades de Araro - en los límites del señorío tarasco - y que el mar cuyo dios detenía la cabeza de la divinidad telúrica, no se encuentra muy lejos en línea recta hacia el occidente; podemos ver que la tierra de la que se habla no es un mundo abstracto e ilimitado, sino algo más cercano al territorio poseído ${ }^{50}$. Considerando lo expuesto sobre las concepciones p'urhépecha del ser humano, podríamos traslapar esta imagen de la tierra al relato de la segunda parte de la Relación y ver que, al igual que en el hombre, es a partir de la unión de los opuestos - caliente-solar, frío-acuáticotelúrico - en el « corazón » o « meollo » - aquí la zona del Lago de Pátzcuaro que se produce la vida y el esplendor del señorío tarasco.

Aunque obviamente el relato presentado por Alcalá ha dejado de ser contado, disponemos de una narración en la que los pobladores de Urapicho ponen en claro las cualidades térmicas de los diferentes grupos que se encuentran al origen de los p'urhépecha actuales. Desgraciadamente, el texto no establece a qué rumbo corresponde cada una de las poblaciones, lo importante es que el ser humano vigente es producto de ambos.

Vinieron indios del sur y del norte. Unos no aguantaron el frío [los más calientes] y los otros el calor [los más fríos]. Entonces aquí permanecieron, aquí vinieron, aquí estamos. Ya no tenemos costumbres como aquellas gentes, nosotros [los verdaderos hombres] somos de otra forma de hablar, de vivir. Ellos comían animales, mieles silvestres que había en los cerros [...] Se los comían crudos. (Reyes Rodríguez et al. 1982, p. 94)

Aunque es casi una obviedad, también debemos remarcar que, en este esquema, el sol - comido y excretado diariamente - sigue la misma trayectoria que los alimentos y, más específicamente, el maíz. Lo interesante es que, como lo muestra Barrera Bassols (2008, comunicación oral) ${ }^{51}$, en una artesanía contemporánea de Pichátaro se representó al rostro solar rodeado de elotes en lugar de rayos. El maíz, cuyo color dominante se asemeja al del helio-astro, requiere de la luz y el calor solar para crecer y desarrollarse; mientras que el hombre, a través de su consumo, adquiere el calor que necesita para vivir (Foster 1972, p. 187). Incluso, en los casos de pérdida de un elemento vital calórico, se han registrado plegarias dedicadas al maíz, suponiéndose que la cura del paciente repercute igualmente en el desarrollo de su cosecha (Gallardo Ruiz 2008) ${ }^{52}$. Así, el cuerpo 
humano sería análogo a la tierra y el ciclo agrícola del maíz comparable al recorrido diario del sol.

Cuerpo y cosmos se refieren uno a otro a través de metáforas.

Una informante de Foster (1972, pp. 130-131) explicó que « una persona pasa por tres «edades» a lo largo de su vida. La primera va del nacimiento a la pubertad, en la que generalmente aumenta el calor - lo que significa salud y vigor corporal. La segunda va de la pubertad a los treinta años y es la del máximo de fuerza y vitalidad. Después de los treinta, la persona pierde su esfuerzo y su cuerpo se va haciendo frío y viejo. Paralelamente, la Segunda Parte de la Relación, vista a posteriori como lo hacían los informantes de Alcalá, comienza cuando el sol-Curicaueri se encuentra en el norte. Es decir, en el solsticio de verano, cuando los días son más cálidos y largos; es en este momento que los uacúsechas son más chichimecas; su dios es poderoso, viven de la caza, son guerreros y no hacen sacrificios humanos $^{53}$. Lo que sigue es la alianza con los fríos lugareños; ello produce una sucesiva pérdida de calor en el viaje hacia el sur-invierno. Los chichimecas llegan a su destino, un sitio ligado a la muerte, cuando los días son más cortos y fríos, y cuando, en el ciclo humano, se está más próximo a la muerte. De ahí, inicia el proceso de renacimiento y los chichimecas comienzan a dominar la tierra, como el sol sale de la oscuridad para viajar hasta el cenit.

\section{CONSIDERACIONES Finales}

Según hemos visto a lo largo de este trabajo, a muy grandes rasgos, es posible dividir nuestra narración en tres partes. La primera da inicio cuando el caudillo se encuentra con la deidad-sol en un cerro de Zacapu y concluye con el conflicto con los lugareños, la huida de los chichimecas y el deceso de su líder. La segunda comprende la etapa migratoria y concluye con la alianza con la gente del Lago y el nacimiento de Tariácuri, el primer unificador del señorío tarasco. Y la tercera involucra los múltiples conflictos con los lugareños y la consolidación del señorío; en un inicio, en tres capitales y, después, en una sola sede.

Considerando que la deidad y el pueblo se representan mutuamente, podemos suponer que muchas de las características que se atribuyen a uacúsechas y lugareños no son más que símbolos de un mundo que se piensa como dividido en dos polos principales. La gente del lago es descrita como vieja, poderosa, rica, alcohólica, lujuriosa, adúltera, hablante de una lengua corrupta o serrana y adepta al uso de conjuros y adivinaciones para derrotar a sus enemigos; estas cualidades se asocian a Xaratanga, la diosa del lago y la tierra. Los chichimecas, por su parte, traen leña a sus dioses, hacen penitencia constantemente, no olvidan las injurias, hacen flechas, son castos, no beben, son buenos cazadores, son jóvenes y pobres; dichas actitudes se vinculan a su dios Curicaueri. Así ser 
considerado como chichimeca o autóctono es una cuestión que depende más del comportamiento que de la filiación o de un determinado modo de vida.

Por lo tanto, si consideramos que deidad y pueblo se representan mutuamente, en la migración chichimeca, el desplazamiento de norte a sur y la revelación de Curicaueri en dos elevaciones al inicio y fin del recorrido estaría simbolizando el movimiento aparente del sol, desde el solsticio de verano - punto más norteño en la salida del helio-astro en el horizonte - al solsticio de invierno - punto más sureño en la visualización del amanecer. En el verano, el día es largo y caluroso pero, como aún no es tiempo de cosecha, escasean los productos agrícolas; en el invierno, justo después de haberse recogido lo sembrado, el alimento es abundante pero los días son cortos y fríos. La pobreza, la juventud, la vida de caza y el origen norteño asocian a los uacúsechas con el solsticio de verano, mientras que el frío, la riqueza, la vejez y su origen sureño vinculan a la gente del lago con el solsticio de invierno.

En el relato existe una transición de lo norteño-caliente-pobre a lo sureñofrío-rico marcada por el proceso migratorio. Después de la aparición de la deidad, el caudillo contrae matrimonio con la mujer lugareña y, a partir de un conflicto, da comienzo el movimiento hacia el meridión. Progresivamente, los días se hacen más cortos y fríos - el helio-astro va muriendo - hasta llegar a Pátzcuaro, un sitio ligado al luto, donde el sol nace de nuevo al revelarse por segunda ocasión. Ahí, se produce la alianza con los lugareños, inicia la vida agrícola y da comienzo la construcción del imperio.

De la unión de los contrarios - chichimecas-sol y lugareños-lago-tierra - nace Tariácuri que, asociado al viento, une a ambos grupos dentro de un mismo reino. Esta misma imagen de síntesis se observa en la división del señorío en tres capitales; Pátzcuaro asociado a Curicaueri-sol, Tzintzuntzan-Michoacán ligado a Xaratanga tierra-lago e Ihuatzio vinculado al Coyote, cuyo oscuro simbolismo parece conectarse al aullido del viento que comunica lo celeste con lo terrestre y lo acuático. La alianza, simbolizada por el intercambio de alimentos y consumada por la recepción de una mujer extranjera, establece una jerarquía en la que los chichimecas fungirían como grupo dominante y los lugareños como sus servidores. El encuentro entre chichimecas y lugareños produce al hombre actual real - mitad cazador y mitad pescador-agricultor - que cuenta ya con las costumbres que tenían los p'urhépecha al momento de contacto con los españoles. El poder fecundante de los chichimecas solares se hace sumamente explícito en la celebración contemporánea de la fiesta de Corpus; cuando los que vienen del cerro intercambian los alimentos silvestres por productos agrícolas cocidos y erectan un poste engrasado en cuya punta se dispone como premio un panal-vagina.

Al mismo tiempo, la unión de pueblos con cualidades opuestas y complementarias resulta análoga al modo en que los indígenas contemporáneos piensan la composición anímica del ser humano; un corazón o centro - rector de la mayoría 
de los procesos mentales - y una suerte de energía bipolar compuesta por un elemento frío y otro caliente que, en un cierto equilibrio, muestra ligera dominancia de la parte de mayor temperatura. Aunque más calor supone un peligro potencial para el entorno, éste también implica un mayor poder; de suerte que, en la vida, un hombre pasaría de un estado frío, al nacimiento, a uno de mayor calor, en la plenitud, y a un nuevo enfriamiento hacia la vejez. Pensando que, en nuestra narración, el juego entre lo frío y lo caliente se produce no en el organismo sino en el territorio, podríamos ver que el surgimiento, migración y renacimiento del pueblo chichimeca solar sería análogo a dichos procesos anímico-corporales y que la alianza final sería comparable al relativo estado de equilibro que se alcanza en la madurez. La historia inicia cuando el día es más largo, el sol está en el cenit y los chichimecas son cazadores. Luego, después de la primera alianza con los lugareños, inicia un proceso de enfriamiento, un viaje hacia el sur en que el día se va haciendo más corto y se aproxima el invierno. Al llegar a su destino, el sol renace y comienza un nuevo proceso de aumento del poder calórico.

El relato es complejo y está lleno de detalles metafóricos, pero encontramos un mensaje sumamente simple expresado una y otra vez al interior de la cultura p'urhépecha. Existen, cuando menos, tres niveles del cosmos: cielo, tierra, infierno (Ramírez 1980, p. 360). Son tres primos, hijos de tres primos, que se convierten en gobernantes de tres capitales con, aparentemente, tres divinidades patronas; Xaratanga, Curicaueri y el Coyote. El hombre se constituye de tres entidades anímicas; una fría, otra caliente y otra más que funge como centro. Tres viejos asesoran y ayudan a Tariácuri, tres sacerdotes se transforman en serpientes tras la transgresión a Xaratanga y se mencionan tres templos, con tres fogones y tres casas de los papas en la primera capital chichimeca. Por último, por estratificada que pudiera haber estado la sociedad tarasca en el siglo XvI, la segunda parte sólo nos menciona tres actividades económicas relevantes; la caza, la pesca y la agricultura.

Las capitales se unifican, las entidades anímicas tienen un centro. Lo triple en el discurso p'urhépecha es, por excelencia, la imagen de síntesis de los opuestos complementarios; lo triple representa al mundo, al orden y al hombre actual.

Considerando que no existe ninguna evidencia de que los tarascos hayan sido cazadores nómadas en los últimos 3000 años, podemos suponer que los relatos de las migraciones chichimecas nos remiten a un discurso esencialmente simbólico. La confrontación y alianza entre cazadores masculinos y solares y agricultores-pescadores, femeninos y acuático-telúricos representa la unión de principios opuestos y complementarios. El desplazamiento de los uacúsechas y su dios-sol en dirección norte-sur y su posterior alianza con los isleños, comparable al movimiento estacional aparente del helioastro en el horizonte, simboliza tanto los orígenes del verdadero tarasco como el cambio en las estrategias económicas a través del ciclo anual. En el plano sociológico, la unión de los lugareños y recién llegados origina un estado dividido en tres capitales. En lo corporal, los compo- 
nentes fríos y calientes, ligados a estos dos tipos de poblaciones, dan vitalidad a un tercer elemento que funge como centro regulador. Son los mismos principios lógicos por los que cuerpo, sociedad y cosmos se refieren uno a otro a través de metáforas. *

* Manuscrit reçu en mai 2008, accepté pour publication en octobre 2009.

\begin{tabular}{|c|c|c|c|}
\hline $\begin{array}{l}\text { ELEMENTOS } \\
\text { COMPARTIDOS }\end{array}$ & TARASCOS & NaHUAS & QUICHÉS \\
\hline $\begin{array}{l}\text { Caza de venado } \\
\text { como origen de } \\
\text { conflictos }\end{array}$ & $\begin{array}{l}\text { Ticatame acordó con los ha- } \\
\text { bitantes de Naranjan que } \\
\text { estos podrian comer cualquier } \\
\text { venado que encontraran fle- } \\
\text { chado siempre y cuando conser- } \\
\text { varan la piel para el culto de } \\
\text { Curicaueri. Al violarse el tabú, } \\
\text { inicia el conflicto. }\end{array}$ & $\begin{array}{l}\text { Mimich le dispara varias flechas } \\
\text { a un venado-mujer, lo quema, } \\
\text { explota en pedernales de colores } \\
\text { y se queda con el blanco para } \\
\text { tenerlo como bulto sagrado; el } \\
\text { venado es la diosa Itzpapalotl. } \\
\text { Lo siguiente es que el protago- } \\
\text { nista va a realizar diversas } \\
\text { conquistas. }\end{array}$ & $\begin{array}{l}\text { Los quichés estaban } \\
\text { destazando un vena- } \\
\text { do cuando pasaron } \\
\text { dos «montañeses de } \\
\text { las parcialidades». } \\
\text { Estos últimos se } \\
\text { sienten irritados por } \\
\text { la acción y dan ini- } \\
\text { cio al conflicto. }\end{array}$ \\
\hline $\begin{array}{l}\text { Deidades } \\
\text { asociadas a } \\
\text { venados }\end{array}$ & $\begin{array}{l}\text { Curicaueri es cubierto con piel } \\
\text { de venado. }\end{array}$ & $\begin{array}{l}\text { Itzpapalotl se convierte en } \\
\text { venado de dos cabezas. }\end{array}$ & $\begin{array}{l}\text { Tohil se convierte en } \\
\text { venado para sacrifi- } \\
\text { car a sus enemigos }\end{array}$ \\
\hline $\begin{array}{l}\text { Son los autócto- } \\
\text { nos quienes ofre- } \\
\text { cen mujeres a los } \\
\text { recién llegados }\end{array}$ & $\begin{array}{l}\text { Cuando la gente de Naranjan se } \\
\text { entera de la alianza entre Tica- } \\
\text { tame y Curicaueri, lo primero } \\
\text { que hacen es ofrecerle una her- } \\
\text { mana como esposa. }\end{array}$ & $\begin{array}{l}\text { Después de haber realizado } \\
\text { grandes conquistas, Mixcoatl se } \\
\text { encuentra, en Huitznahuac, con } \\
\text { una mujer desnuda llamaba } \\
\text { Chimalma, se acuesta con ella y, } \\
\text { en seguida, sus hermanos } \\
\text { mimixcoa deciden asesinarlo y } \\
\text { enterrar su cuerpo en la arena. }\end{array}$ & $\begin{array}{l}\text { Los señores de las } \\
\text { parcialidades tratan } \\
\text { de corromper a los } \\
\text { "nawales de Tohil " } \\
\text { enviando a tres vír- } \\
\text { genes para que los } \\
\text { seduzcan. }\end{array}$ \\
\hline $\begin{array}{l}\text { Se presenta a los } \\
\text { recién llegados } \\
\text { como "salvajes" } \\
\text { o " silvestres" }\end{array}$ & $\begin{array}{l}\text { Carecen de agricultura, viven de } \\
\text { la caza, son vistos como agresi- } \\
\text { vos. }\end{array}$ & $\begin{array}{l}\text { Visten con pieles, habitan en las } \\
\text { cuevas, viven de la caza, desco- } \\
\text { nocen el fuego. }\end{array}$ & $\begin{array}{l}\text { Visten con heno, no } \\
\text { tienen agricultura, } \\
\text { desconocen el fuego. }\end{array}$ \\
\hline $\begin{array}{l}\text { El lugar de ori- } \\
\text { gen es paralelo al } \\
\text { de llegada, en } \\
\text { ambos sitios se } \\
\text { revela la divini- } \\
\text { dad }\end{array}$ & $\begin{array}{l}\text { Zacapu y Pátzcuaro son pue- } \\
\text { blos en las riberas de un lago. }\end{array}$ & $\begin{array}{l}\text { Aztlan y Tenochtitlan son islo- } \\
\text { tes en medio de un lago. }\end{array}$ & \\
\hline $\begin{array}{l}\text { La deidad } \\
\text { patrona se rela- } \\
\text { ciona a lo ígneo y } \\
\text { solar }\end{array}$ & $\begin{array}{l}\text { Curicaueri es la deidad del } \\
\text { fuego y el sol. }\end{array}$ & $\begin{array}{l}\text { Itzpapalotl es el pedernal con } \\
\text { que se enciende el fuego. Huitzi- } \\
\text { lopochtli es una deidad solar } \\
\text { que funge como guía. }\end{array}$ & $\begin{array}{l}\text { Es Tohil quien da } \\
\text { fuego a su pueblo. }\end{array}$ \\
\hline $\begin{array}{l}\text { El resultado de } \\
\text { la historia es la } \\
\text { formación de rei- } \\
\text { nos tripartitas }\end{array}$ & $\begin{array}{l}\text { Pátzcuaro, Tzintzuntzan e } \\
\text { Ihuatzio }\end{array}$ & $\begin{array}{l}\text { Tenochtitlan, Texcoco y Tlaco- } \\
\text { pan }\end{array}$ & $\begin{array}{l}\text { Los Cawekib, los } \\
\text { Nijaib y los Ajaw } \\
\text { Q'uiché }\end{array}$ \\
\hline $\begin{array}{l}\text { Borrachera de } \\
\text { señores o deida- } \\
\text { des que anuncia } \\
\text { la caída del reino }\end{array}$ & $\begin{array}{l}\text { Zuangua estaba borracho } \\
\text { cuando los sacerdotes de Cue- } \\
\text { rauaperi fueron a anunciarle el } \\
\text { presagio de la llegada de los } \\
\text { españoles. }\end{array}$ & $\begin{array}{l}\text { Quetzalcoatl se embriaga antes } \\
\text { del fin de Tula, Tezcatlipoca } \\
\text { aparece ebrio para anunciar la } \\
\text { destrucción de Tenochtitlan }\end{array}$ & \\
\hline
\end{tabular}

TABLA - Coincidencias en algunos episodios de migración y fundación de señoríos. 


\section{Notas}

1. Seler (2000, pp. 151-152) ya había notado similitudes entre el p'urhépecha, el maya y las lenguas andinas. Swadesh (1967-1968) sugiere la existencia de semejanzas más concretas entre el p'urhépecha, el zoque y las lenguas mayances que con los idiomas de la familia quechua-aymara. Liedtke (2001, pp. 57-68) reanaliza el material tratado por Swadesh y, tras hacer una dura crítica a su metodología, encuentra aún más coincidencias entre el quechua y el p'urhépecha de las que originalmente se habían señalado. Greenberg (1987, p. 106), en su clasificación de lenguas amerindias, vincula al p'urhépecha con el chibcha. Anawalt (2000) presenta evidencias de un antiguo comercio transpacífico entre Occidente y Ecuador. Cárdenas Fernández (2003, p. 65) y Hurtado Mendoza (1986, p. 14) proponen un franco origen peruano de dicha cultura. Carot y Hers (2006) sostienen la existencia de cierta interacción entre los antiguos p'urhépecha, los chalchihuiteños y los llamados pueblos ancestrales del Suroeste de Estados Unidos.

2. De hecho, la autora menciona la presencia de cerámica Loma Alta en niveles antiguos de sitios posclásicos, en particular Tzintzuntzan y Erongarícuaro.

3. A través de los cambios en el patrón de asentamiento, los tipos cerámicos y los sistemas funerarios, Michelet et al. (2005) han logrado documentar la intrusión de nuevos grupos en la región de Zacapu hacia $1250 \mathrm{dC}$.

4. Claro que nuestra fuente (Relación de Michoacán 2008, fol. 62v) nunca dice de dónde vinieron Hireti Ticatame y Curicaueri; en realidad el texto sólo dice: «El empenzó su señorio donde llegó al monte llamado Virúguarapexo, monte cerca del pueblo de Çacapo tacánendan ».

5. Haskell (2008, pp. 231-241) procura leer, entre las líneas del discurso histórico de la Relación, la lógica de la estructura social indigena. Estariamos de acuerdo con él en que lo más interesante del relato es descubrir "la "lógica cultural" del discurso como un todo y, por lo tanto, sin ligar o dividir la narrativa en eventos útiles "reales" y elementos menos útiles "míticos" " (ibid., p. 233; todas las traducciónes de Haskell son del auteur, R. M. G.).

6. Además de plantear un nexo entre lo histórico y lo religioso en el relato tarasco, Michelet (1989) se da cuenta de que la historia fue manipulada para resaltar la parte relativa a los ancestros fundadores. Al notar que los datos arqueológicos no muestran la presencia de pueblos cazadores en época tarasca, afirma que « la imagen del uacusecha bárbaro debería así ponerse radicalmente en duda [...]. El mensaje proporcionado por la $R M$ aparece en buena parte fabricado, sin duda bajo la influencia de una visión arquetípica del pasado que los tarascos del siglo Xvi habrian compartido, en gran medida, con los mexicas ». Franco Mendoza (2000a; 2000b), partiendo del análisis del discurso que el petamuti pronunciaba en « la fiesta de las flechas », reconoce la existencia de una cierta estructura, recurrente en otros discursos, que tiende a subrayar la unidad del imperio tarasco, su identificación con la deidad patrona y la legitimidad del cargo señorial en el cazonci. A través de este discurso, se busca infundir " valores cívicos, éticos, religiosos, políticos, o de otra naturaleza para mantener el orden divinohumano en el irechequa ".

7. Espejel (2008) encuentra semejanzas entre la Relación y las Siete Partidas de Alfonso X el Sabio y, a partir de ello, sostiene que el papel del fraile redactor fue más activo de lo que él hizo creer y que « en su papel de intérprete no transcribió tan fielmente las palabras de sus informantes y que, de hecho, su interpretación afectó profundamente la imagen de la sociedad que plasmó en el documento ». No obstante dicha autora no descarta la posibilidad de comprender a través de dicho escrito la visión indigena del murido. Según esta investigadora, el fraile introdujo el concepto de justicia como principal medio para conservar el orden de Dios. Sin embargo, también pudo reconocer una voz indígena en la que el discurso se ordena alrededor del culto a la deidad del fuego. « Dependiendo de la clave con que se lean, los datos de la Relación adquieren diferentes significados y, en consecuencia, cada lectura genera una imagen distinta de los tarascos ".

8. Según la autora, los uacúsechas traen el uso del arco y la flecha « que habían adoptado a raíz de sus contactos con los pueblos ancestrales del Suroeste de los Estados Unidos ». 
9. En el registro arqueológico es « patente que las novedades detectadas, de ninguna manera pueden atribuirse a poblaciones cazadoras-recolectoras nómadas inexpertos en los detalles de la vida sedentaria al estilo general mesoamericano " (Michelet et al. 2005, p. 138).

10. Ticatame acordó con los habitantes de Naranjan que éstos podrían comer cualquier venado que encontraran flechado siempre y cuando conservaran la piel para el culto de Curicaueri. Los lugareños « no lo sabían desollar que hacían pedazos el pellejo » y, por tal motivo, el caudillo de los cazadores decide flecharlos; acto seguido, los uacúsechas deben huir (Relación de Michoacán 1980, p. 24). En un pasaje tanto más confuso, el Titulo de Totonicapán (1983, p. 188) indica que los quichés " estaban destazando un venado frente a la casa, cuando pasaron dos montañeses de las parcialidades. De repente dijeron: - ¿Quién destaza? Sólo a nosotros nos toca eso. ¿Serán nuestros hermanos los que ustedes están destazando?, dijeron los de las parcialidades. Así de nuevo empezó la guerra ». Por último, se cuenta que, en tiempo de las migraciones toltecas-chichimecas, bajaron 2 venados de 2 cabezas; los mimixcoa Mimich y Xiuhnel los persiguen para cazarlos. « Una noche los persiguieron y lo mismo un día; y ya a la puesta del sol los cansaron [...]. Luego fueron a pasearse los que eran venados y ya se convierten en mujeres ». Mimich le dispara varias flechas a un venado-mujer, lo quema, explota en pedernales de colores y se queda con el blanco para tenerlo como bulto sagrado; el venado es la diosa Itzpapalotl. Lo siguiente es que el protagonista va a realizar diversas conquistas (Leyenda de los soles 1945 , p. 124).

11. En otro trabajo (Martínez González 2007, pp. 22-24), hemos dicho que, para otros pueblos mesoamericanos, el hecho de cubrirse con la piel de un animal es muchas veces visto como un cambio de forma.

12. «- Mirad que muy altamente ha sido engendrado Curicaueri y con gran poder ha de conquistar la tierra. Aquí tenemos una hermana, llevádsela y ésta no la damos a Hiretiticatame, mas a Curicaueri, y a él le decimos lo que dijéremos a Hiretiticatame. Y hará mantas para Curicaueri, y mantas para abrigarle y mazamorras y comida para que ofrezcan a Curicaueri, y a Hiretiticatame ». Los lugareños planean la forma de doblegar a los uacúsechas Pauacume y Uapeani: «-Cada uno de nosotros tiene una hija y trairémoslos aquí a las islas y casaríamoslo con ellas. Y el uno de aquellos señores sería sacrificador aquí en la orilla en este cu, y el otro sería sacerdote en Quacarixangatien y sacrificaría allí » (Relación de Michoacán 1980, pp. 43-44). En el caso de Tariácuri, el primer matrimonio no implica una automática pérdida de poder; pues, su mujer le era infiel y regresó a vivir con los suyos casi inmediatamente. Sin embargo, es después de sus segundas nupcias que padece la invasión de su primer suegro y que comienza a buscar, en sus sobrinos Hiripan y Tangaxoan, su relevo en el cargo señorial (ibid., pp. 100-121).

13. No es tan claro que Tojil sea una deidad solar, mas su carácter ígneo es puesto en relieve cuando da el fuego a los hombres: « No tenían fuego [...] entonces él (Tojil) sacó fuego de la sandalia del icono. Prendió el fuego y se los dio » (Título de Pedro Velasco 1989, p. 175).

14. Cabe aclarar aquí que el objetivo de este trabajo no es establecer si existió o no una cierta unidad política, social o cultural entre las poblaciones tratadas; lo que nos interesa es justamente la dimensión simbólica del relato y, por consiguiente, resultan más pertinentes los estereotipos que las características reales de los grupos mencionados por nuestra fuente.

15. Coringuaro es mencionado como de "población divina " y "tiene canas de muy antigua población ". Aunque se dice que es un pueblo de origen chichimeca, se da a entender que éste lleva tanto tiempo asentado en la región que ha terminado por adoptar las cualidades de los autóctonos.

16. Tangaxoan dice a Hiuacha: «- ¿Quién te dijo que cuentes los días? Nosotros no peleamos contando de esa manera los días, mas traemos leña para los cues y el sacerdote llamado curi y el sacrificador, toman olores para la oración de los dioses. De noche estamos en nuestra vela para mirar como va la gente y para despedirlos, y con esto peleamos " .

17. No beber es algo que se asocia a la clase sacerdotal: " era de su oficio no emborracharse » (Relación de Michoacán 1980, p. 141). Según Michelet (1989, p. 112), la bebida y las relaciones extramaritales se presentan como los principales obstáculos para el acceso a la realeza y, desde la aparición de Tariácuri, son señalados como peligrosos para la sociedad. Franco Mendoza (2000b, p. 270) ve la conquista de los lugareños como un proceso de purificación. 
18. Al respecto, Michelet $(1989$, p. 110) ya había comentado que « la "barbarie" o el "carácter primitivo" de los uacúsechas es tan mencionado y puesto en valor, que da la impresión de una identidad inventada o, por lo menos, forzada ».

19. También se menciona el caso de un lugareño, llamado Chapa, que se chichimequiza al adoptar como patrono a Curicaueri y comenzar a ofrecerle cautivos (Relación de Michoacán 1980, p. 140). En el mismo sentido, los primos de Tariácuri que no son dignos de ser señores chichimecas, Zetaco y Aramen, andaban emborrachándose y con mujeres (ibid., p. 60).

20. Es por ello que la Relación (2008, pp. 20,27) llama a los uacúsechas « los del linaje de nuestro dios Curicaueri ", mientras que los que tienen a Uazoriquare por deidad tutelar se refieren unos a otros como " hermanos".

21. En este trabajo, se entiende el " contacto directo » como la creencia en la posibilidad de ciertos individuos de encontrarse e interactuar con la sobrenaturaleza, sin que ello implique necesariamente un estado de conciencia particular.

22. En ningún momento parece sugerirse una total identificación; nunca se llama al gobernante Curicaueri - cosa que sí sucede con algunos ritualistas -, no se le denomina "dios» y, en todo momento, se establece con claridad que él « está en lugar de Curicaveri ». Al mismo tiempo, ningún dato nos asegura que todos los gobernantes estuvieran igualmente dotados de poderes sobrenaturales que los verdaderos especialistas rituales. Sino que, por el contrario, era usual que se valieran de intermediarios para comunicar con las divinidades patronas (Relación de Zapotlan en Relaciones geográficas del siglo xи 1987, p. 391; Códice Plancarte 1959, pp. 9-10, 14-15).

23. Más allá de la manipulación de la historia con una intención política, se trata aquí de una cierta manera de narrar el desarrollo de un pueblo a través de sus emblemas - lo que a la luz de la historia oficial de los Estados modernos no es infrecuente. Por tratarse de una historia oral y en continua interpretación, sería ingenuo pensar en la existencia de un " original " susceptible de ser alterado antes de su escritura en caracteres latinos. En lo referente a este último caso, cabe recordar que Michelet (1989, p. 112) ya había esbozado la posibilidad de que la oposición entre bebida-adulterio-fracaso y castidad-penitencia-éxito fuera producto de la intervención del fraile compilador en la estructura de la narración.

24. El propio autor de la Relación de Michoacán (2008, p. 63) explica sobre el texto " no va contando mas de los señores, y casi las más veces nombra los señores qué decían o hacían, y no nombra la gente ni los lugares donde hacian su asiento y vivienda ".

25. "Etimológicamente Curicaueri o Curicuaueri podría interpretarse como una secuencia de dos palabras: el sustantivo ueri y el adjetivo curica [...] El sustantivo ueri se interpreta como [...] "el que sale" [...] El adjetivo curica y el sustantivo curicua están formados por la raíz verbal curi. Del verbo curicani "hazer lumbre" [...] La grafia Curica ueri se traduciria como "el sale haciendo fuego" [... o] "el fuego que sale ardiendo" " (Monzón 2005, p. 143).

26. Se habla de « las mieses que había traído Xaratanga a la tierra: Aji colorado y verde y amarillo [...] frijoles colorados y negros [...] el maíz colorado y lo pintado [...] otras maneras de maiz, de lo blanco $y$ de lo entrevarado ».

27. « $\mathrm{Y}$ displaciendo esto a la diosa, no se les pegó el vino, que todo lo echaron y vomitaron [...] ¿Cómo habían de tomar pescado que se lo había ya escondido Xaratanga, que era tan gran diosa? » Zurumban, uno de los sacerdotes de esta deidad, « se emborrachaba cada día y nunca lo dejaba de la boca; y tenía una guirnalda de hilo en la cabeza, que era sacerdote de Xaratanga ».

28. Para los chichimecas las flechas son dioses mientras que los del lago las queman. Tariácuri explica a sus sobrinos: «- Estas flechas son dioses, con cada una de éstas mata nuestro dios Curicaveri y no suelta dos flechas en vano ". En otra ocasión, el mismo señor regala unas flechas de colores a los isleños y estos deciden quemarlas: « - Mejor fuera que no las quemárades sino que buscáramos un cuero o carcaj y las pusiéramos en él y se las pusiéramos a nuestro dios Urendequauecara: porque deben tener alguna deidad estas flechas y viviera nuestro dios algunos días con ellas " (Relación de Michoacán 1980, pp. 118, 151).

29. Es notable que hasta las mujeres chichimecas tienen cualidades masculinas; esto se ve en la historia de una hija o mujer de Tariácuri que seduce a un señor de Coringuaro para, como guerrero, 
cortarle la cabeza (Relación de Michoacán 1980, pp. 207-212). En el lado opuesto tenemos que, aunque los lugareños ofrecen mujeres a los chichimecas en múltiples ocasiones, estos no tienen relaciones sexuales con las féminas uacúsechas ni siquiera cuando las capturan: «- ¿Quien os dijo que trajésedes sus hermanas? Llevadlas al cu de Paruaten y sacrificadlas y echadlas en la laguna a las bellacas, malas mujeres! » (ibid., p. 84).

30. Se trata de un sitio relacionado con la fertilidad que, a raíz de dicha comunicación, se convertiría en un importante lugar de culto y de contacto con el otro mundo. « [En Tzacapu] está un cerro, en cuya cumbre está labrado un vaso tan perfecto, que sólo la naturaleza pudo ser artífice de su fábrica, porque todo el cerro es redondo y, por dentro, hueco y lleno de agua [...] Las aguas son clarísimas y deleitosas, y así han movido a admiración, a cuya novedad han ido de muchas partes a verlo [...] El ídolo principal y único (que no tuvieron otro los tarascos) estuvo en el pueblo de Tzacapu, metrópoli de Mechoacan y matriz de su grandeza, como Roma de todo el mundo; cuyo templo estaba en la cumbre de un monte que sus faldas vienen a ser vecinas del mismo pueblo " (Rea 1996, pp. 68-82).

31. De Pátzcuaro se dice: «Andaban mirando las aguas que habia en el dicho lugar, y como las vieron todas, dijeron: - Aquí es, sin duda, Pátzcuaro; vamos a ver los asientos que hemos hallado de los cúes. Y fueron [a] aquel lugar, donde ha de ser la iglesia catedral, y hallaron alli los dichos peñascos llamados petátzequa, que quiere decir asiento de $\mathrm{cu}$. Y está allí un alto y subieron alli y llegaron [a] aquel lugar, y estaban allí encima unas piedras alzadas como idolos, por labrar, y dijeron:-Ciertamente, aquí es: aquí dicen los dioses, que estos son los dioses de los chichimecas, y aquí se llama Pátzcuaro donde está el asiento. Mirad que esta piedra es la que se debe llamar Ziritacherengue, y esta Uacúsecha, que es su hermano mayor, y esta Tingárata y esta Miequa-axena. Pues mirad que son cuatro estos dioses. Y fueron a otro lugar que decían sus dioses y dijeron: - Escombremos este lugar. Y así cortaron las encinas y árboles que estaban por alli, diciendo que habían hallado el lugar que sus dioses les habían señalado. Este susodicho lugar, tuvieron sus antepasados en mucha veneración, y dijeron que aquí fue el asiento de su dios Curicaueri. Y decía el cazonci pasado, que en este lugar y no en otro ninguno, estaba la puerta del cielo, por donde descendian y subían los dioses " (Relación de Michoacán 2000, p. 364; López Austin 1976, p. 221).

32. Tal como señala Graulich (1997, p. 141), « en el pensamiento mesoamericano la migración de un pueblo es a menudo presentada como un viaje en el inframundo y la llegada a la tierra prometida como la salida del sol [...] Antes de salir del inframundo y llegar a su tierra, los mexicas, representados por su dios solar, tienen que triunfar sobre las fuerzas de las tinieblas, telúricas, pasivas, femeninas, y los migrantes tienen que vencer a los autóctonos. Sólo esto hace posible la llegada a la tierra prometida y el advenimiento de una nueva era o edad, un nuevo "Sol" ". Los nahuas explican que "vivieron los chichimecas aun en tinieblas " (Anales de Cuauhtitlan 1945, p. 4). En el caso quiché, se dice explícitamente que los ancestros " vinieron de la obscuridad de la noche [...] Sólo estaban esperando la aurora » (Título de Pedro Velasco 1989, p. 174). Y, así como entre los tarascos, es donde sale el sol que se asientan los peregrinos: « Tojil fue llevado dentro de un gran bosque [...] se encontraba alli el ídolo de Balam Q'itsé. El ídolo de Balam Ak'ab fue llevado a Pawilix, al bosque escondido. El ídolo de Majucotaj se quedó alli mismo sobre el cerro de Jak'awits, y allí estaba cuando amaneció » (Título de Totonicapán 1983, pp. 184-185).

33. Castro Leal (1986, p. 187) ya se había dado cuenta de la omisión de Ihuatzio pero supone que esta pudo haber formado parte de Tzintzuntzan.

34. Tal como señala Haskell $(2008$, p. 235$)$, « este matrimonio unifica categorías fundamentalmente opuestas que portan significado en todos los aspectos de la vida. En esencia, su unificación produce una totalidad, y es, por lo tanto, esta unidad de chichimecas e isleños quien gobernará sobre la tierra. Además el resultado de esta unión es el héroe cultural Tariácuri ».

35. Nótese que las condiciones del pacto original entre migrantes y autóctonos son bastante semejantes en otras partes de Mesoamérica. Una vez que los quichés derrotan a las parcialidades, los vencidos dicen: «- Por favor no nos maten, dijeron. - Está bien, ciertamente no morirán ustedes las parcialidades, les respondieron los señores a las parcialidades. - Pero ustedes serán siervos para siempre » (Titulo de Yax 1989, p. 78). « Mexico-Tenochtitlan se compone de autóctonos y de invasores 
mexicas. De manera muy reveladora, cuando los guerreros emigrantes arriban a la tierra prometida, su dios Huitzilopochtli es acogido por nada menos que el dios autóctono por excelencia, la misma tierra, el sacerdote Tlaloc. Éste dice a su "querido hijo" "viviremos ambos juntos sobre la tierra" " (Códice Aubin 1981, p. 17 in Graulich 1997, p. 150). «El medroso y cobarde no debe atreverse a las cosas de la guerra sino labrar la tierra y hacer maizales » (Sahagún 1956, pp. 2-111; Ruiz de Alarcón 1892, pp. 150-151 in Graulich 1997, p. 143).

36. Ticatame dice " - Ando al campo por dar de comer al sol y a los dioses celestes y de las cuatro partes del mundo y a la madre Cuerauaperi con los venados que flechamos y yo hago salva a los dioses con vino y después bebemos nosotros en su nombre [...] Con ellos damos de comer al sol y a los dioses celestes engendradores y a las cuatro partes del mundo » (Relación de Michoacán 1980, pp. 22, 38). La primera vez que se menciona un sacrificio humano por parte de los chichimecas es cuando Tariácuri captura a Naca: « - Llevadle al cu y sacrificadle » (ibid., pp. 75, 110); mientras que los lugareños ofrecen víctimas humanas, prácticamente, desde el inicio (ibid., pp. 59-60). Carot (s. d., p. 36) dice que los uacúsechas " son portadores de un nuevo culto, con la famosa figura del Chac Mool y el ritual de sacrificio humano ". Al menos, la Relación no parece apoyar este supuesto.

37. Faugère (2008, p. 128) dice que « el paquete sagrado de Curicaueri presenta la particularidad de estar envuelto en una piel de venado ". Sin embargo, cabe notar que esto sólo es mencionado al inicio del relato y que, en la única imagen en que aparece dicho objeto, no figura nada semejante a un pellejo de ciervo (Relación de Michoacán 2008, fol. 118).

38. Cabe aclarar que los uacúsechas no son los únicos que se conciben a sí mismos como recién llegados, sino que el propio término p'urhépecha parece indicar la autoconcepción como extranjero. Ya que, en la lengua actual de Charapan, los términos derivados de phorhé contienen la idea de cierta movilidad, una visita o algo que llega (Velásquez Gallardo 1978, p. 180; Chamoreau 2007, p. 151). Incluso, los documentos antiguos tienden a señalar como habitantes originales de la región a grupos nahuas (Relación de Michoacán 1980, p. 20). Independientemente de que sea cierto o no, esto se evidencia en que el término tarasco para " México ", Echero, contiene la raíz de "tierra " echeri (Diccionario grande de la lengua... 1991, I, p. 492).

39. En el Lienzo de Jucutacato (según la reproducción del Museo Nacional de Antropología) donde las glosas son nahuas pero los personajes visten a la manera tarasca - se ve a los hombres iniciar su peregrinaje al salir de la boca de una olla que asemeja una cueva.

40. No ignoramos que la ceremonia de Corpus es una reelaboración que, aunque parte del pensamiento indigena, atraviesa la religión católica. Sin embargo, como este trabajo está más dirigido a la comprensión del pasado que al entendimiento de las dinámicas sociales de la actualidad, lo que nos interesa aquí son las reminiscencias; esas lógicas rituales que, a pesar de los grandes cambios en la cultura, tienden a subsistir. Rituales semejantes son celebrados en la misma ocasión en otras comunidades de tradición p'urhépecha; ver, por ejemplo, Saldivar (1993, p. 162) para el caso de Tzintzuntzan

41. La asociación con lo chichimeca se hace todavia más evidente en el caso de un personaje que, conocido como el moreno, se unta de tizne - igual que Curicaueri y los chichimecas - para divertir a la gente (Castilleja 2007, p. 346).

42. Estos se opondrian al término generalmente usado para decir "gente » khuiripu, khuiripeta " carne » (Velásquez Gallardo 1978, p. 159; Gallardo Ruiz 2005, p. 83).

43. Todavía en el siglo xx, el Lic. Eduardo Ruiz (en Hurtado Mendoza 1986, p. 9) recogió un canto ritual p'urhépecha en el que se dice " Mi corazón [minzita] muchas cosas recuerda ». Pudiera pensarse que el lenguaje usado por Alcalá no tiene por qué reflejar el modo en que se expresaban en p'urhépecha las sensaciones y sentimientos. Sin embargo, el propio cronista explica: «Ilustrísimo Señor, esta escritura y relación presentan a Vuestra Señoría los viejos de esta Ciudad de Michoacán y yo también en su nombre, no como autor sino como intérprete de ellos. En el cual Vuestra Señoría verá que las sentencias van sacadas al propio, de su estilo de hablar, y yo pienso de ser notado mucho en esto, mas como fiel intérprete no he querido mudar de su manera de decir, por no corromper sus sentencias " (Relación de Michoacán 1980, pp. 4-6). 
44. "Baho », suhuanda; " esta raíz, çuhua-, significa bahear en la parte señalada » (Diccionario grande... 1991, I, pp. 98, 279; II, p. 101; Gilberti 1997, p. 66). Çuhuarani « humear algo » (Gilberti 1997, p. 66). Suánda « vapor » (Velásquez Gallardo 1978, p. 185).

45. Durante la plática que presentó en el seminario del Grupo Kw'aniskuyarhani el pasado 29 de marzo de 2008.

46. "Tales "aires" pueden referirse también a entidades materiales (frio, corriente de aire, viento, emanaciones diversas, etc.) como a seres invisibles con representaciones muy variables (dioses, espíritus, manes, almas del purgatorio, etc.) [...] Cualquiera que sea su naturaleza, se dice que puede introducirse en el cuerpo por todos los orificios naturales (boca, nariz, etc.) o patológicos (llagas) o también durante una inyección o una intervención quirúrgica. En tales casos acarrean enfermedades ("frias" por supuesto) que se curarán por procedimientos de los cuales se dice que calientan el cuerpo al mismo tiempo que evacuan los 'aires' que lo penetraron (su salida se acompaña frecuentemente con un ruido) » (Motte-Florac 1997, p. 191).

47. Aun cuando el susto pueda ser causado por eventos que nosotros veríamos como accidentes, se supone que estos se originan por transgresiones morales $\mathrm{u}$ omisiones rituales que desencadenan castigos por parte de ritualistas locales o entidades sobrenaturales. « Si bien los términos nativos para enfermedades como el aire (Tarhiata pani) y la mollera (Jurhiata pani) se pueden traducir como "se lo llevó el viento" y como "se lo llevó el sol" respectivamente, los médicos tradicionales no hablan de que el viento o el sol sean divinidades que "atrapen" a la sombra del enfermo: parte de la curación para una y otra enfermedad es "levantar la sombra", "llamarla" para que regrese » (Gallardo Ruiz 2005, p. 90).

48. "Las cualidades "caliente" o "frío" se atribuyen a todos los elementos del mundo temporal (astros, plantas, alimentos, enfermedades, etc.) siguiendo criterios esencialmente metafóricos, morfológicos, organolépticos, etc. » (Motte-Florac 1997, p. 187).

49. Si la tierra es un cuenco, el primer recuadro del Lienzo de Jucutacato estaría mostrando a hombres saliendo de la tierra.

50. «Aquellas fuentes echan vaho de sí y decian que de alli salían las nubes para llover y que las tenía en cargo esta diosa Cuerauaperi y que ella las enviaba de oriente donde estaba » (Relación de Michoacán 1980, p. 12).

51. Durante la plática que presentó en el seminario del Grupo Ku'anískuyarhani el pasado 29 de marzo de 2008.

52. Durante la plática que presentó en el seminario del Grupo Kw'aniskuyarhani el pasado 29 de marzo de 2008 .

53. « Los chichimecas adoraban al sol » (Relaciones geográficas del siglo xvt 1987, p. 63).

\section{REFERENCIAS CITADAS}

AjoFrín Francisco de

1986 Diario del viaje a la Nueva España, Heriberto Moreno (ed.), Cien de México, SEP, México.

Alcalá Jerónimo de

1980 Relación de Michoacán, Francisco Miranda(ed.), Fimax Publicistas, Morelia.

2000 Relación de Michoacán, Moisés Franco Mendoza et al. (eds), El Colegio de Michoacán, Gobierno del Estado de Michoacán, Zamora.

2008 Relación de Michoacán: Instrumentos de consulta, Claudia Espejel (ed.) y Carlos Alberto Villalpando (desarrollo), El Colegio de Michoacán, Zamora. 
Anales de Cuauhtitlan

ver Códice Chimalpopoca

Anawalt Patricia Rieff

2000 "Ellos venían a comerciar cosas exquicitas: antiguos contactos entre Ecuador y el Occidente ", in Richard F. Townsend y Carlos Eduardo Gutiérrez Arce (eds), El antiguo Occidente de México. Arte y arqueología de un pasado desconocido, The Art Institute of Chicago/Secretaría de Cultura del Gobierno de Jalisco/Tequila Sauza, Guadalajara, pp. 236-253.

BARTHES Roland

1980 Mitologias, Héctor Schmucler (trad.), Siglo xxi, México.

Beaumont Pablo

1932 Crónica de Michoacán, 3 tomos, Publicaciones del Archivo General de la Nación/Talleres Gráficos de la Nación, México.

BrodA Johanna

1991 «Cosmovisión y observación de la naturaleza: el ejemplo del cultó a los cerros », in Johanna Broda, Lucrecia Maupomé y Stanislaw Iwaniszewski (eds), Arqueoastronomia y etnoastronomía en Mesoamérica, IIH, UNAM, México, pp. 461-500.

2001 "Astronomía y paisaje ritual: el calendario de horizonte de CuicuilcoZacatepetl », in Johanna Broda, Stanislaw Iwaniszewski y Arturo Montero (eds), La montaña en el paisaje ritual, IIH, UNAM, ENAH, INAH, SEP, México, pp. 173-199.

CÁRdenas Fernández Blanca

2003 Los cuentos en lengua p'orhé: un punto de vista sociocrítico, Universidad Michoacana de San Nicolás de Hidalgo/Presses universitaires de Perpignan, Morelia.

\section{CARot Patricia}

s. d. "Capítulo 4: La larga historia purépecha », in Marie-Areti Hers (ed.), Miradas renovadas al occidente de México, IIE, UNAM, México [mecanuscrito en prensa].

\section{CARot Patricia y Marie-Areti Hers}

2006 « La gesta de los toltecas chichimecas y de los purépechas en las tierras de los antiguos pueblos ancestrales ", in Carlo Bonfiglioli, Arturo Gutiérrez, María Eugenia Olavarría (eds), En las vías del noroeste 1: una macroregión indigena americana, IIA, UNAM, México, pp. 47-82.

Castilleja González Aída

2004 "La cha'nantskua o fiesta del Corpus en pueblos purépechas », in Johanna Broda y Catherine Good Eshelman (eds), Historia y vida ceremonial en las comunidades mesoamericanas: los ritos agrícolas, INAH, UNAM, coll. «Etnografía de los Pueblos Indígenas », México, pp. 387-413.

2007 Construcción social y cultural de categorías referidas al espacio. Un estudio en pueblos purépecha, tesis de doctorado en Antropología, ENAH, INAH, SEP, México. 
Castro Leal Marcia

1986 Tzintzintzan. Capital de los tarascos, Gobierno del Estado de Michoacán, Morelia.

\section{Chamoreau Claudine}

2007 «La pluridenominación de una lengua: un juego de doble reflejo. Un acercamiento a la lengua de Michoacán o juchari anapu o tarasco o purépecha », in Pedro Márquez (ed.), ¿Tarascos o P'urhépecha? Voces antiguas y nuevas discusiones en torno al gentilicio michoacano, IIH/Universidad Michoacana de San Nicolás de Hidalgo/El Colegio de Michoacán/Gobierno del Estado de Michoacán/Universidad Indígena intercultural de Michoacán/Grupo Kw'anískuyarhani de Estudios del Pueblo Purépecha/Fondo Editorial Morevallado, Morelia, pp. 141-156.

Códice Chimalpopoca. Anales de Cuauhtitlan y Leyenda de los soles

1945 Primo Feliciano Velázquez (ed.), IIH, UNAM, México.

\section{Códice Plancarte}

1959 José Corona Núñez (ed.), Universidad de Michoacán, coll. «Siglo Xvı », Morelia.

\section{CORONA NúÑEZ José}

1948 "Esquema de deidades de los tarascos antiguos », Cuarta reunión de mesa redonda: el Occidente de México, Museo Nacional de Historia, Sociedad Mexicana de Antropología, México, pp. 139-145.

1993 « La religión de los tarascos », in Angelina Macías Goytia y Lorena Mirambell Silva (eds), La arqueología en los Anales del Museo Michoacano (Épocas I y II), INAH, SEP, México, pp. 369-408.

Diccionario grande de la lengua de Michoacán

19912 vols, Benedict Warren (ed.), Fimax Publicistas, Morelia.

ESPEjel Carbajal Claudia

2008 La justicia y el fuego. Dos claves para leer la Relación de Michoacán, El Colegio de Michoacán, Zamora.

\section{FAUGÈre Brigitte}

2008 "Le cerf chez les anciens P'urhépecha du Michoacan (Mexique): guerre, chasse et sacrifice », Journal de la Société des Américanistes, 94 (2), pp. 109-142.

\section{FosTER George}

1972 Tzintzuntzan: los campesinos mexicanos en un mundo de cambio, FCE, México.

Franco Mendoza Moisés

2000a "Ediciones de la Relación de Michoacán », in Jerónimo de Alcalá, Relación de Michoacán, Moisés Franco Mendoza et al. (eds), El Colegio de Michoacán, Gobierno del Estado de Michoacán, Zamora, pp. 17-35.

2000b "El discurso del Petamuti en la estructura de la lengua p'urhépecha », in Jerónimo de Alcalá, Relación de Michoacán, Moisés Franco Mendoza et al. 
(eds), El Colegio de Michoacán, Gobierno del Estado de Michoacán, Zamora, pp. 265-284.

\section{GallaRdo Ruiz Juan}

2005 Medicina tradicional p'urhépecha, El Colegio de Michoacán, Universidad Indígena Intercultural de Michoacán, Zamora [segunda edición].

2008 "Canto al maíz del cielo: Ceremonial nocturno de curación y de propiciación de la cosecha », comunicación presentada el 29 de marzo 2008 en el seminario del grupo Kw'aniskuryarhani, Pátzcuaro [mecanuscrito inédito del autor].

\section{GiLberti Maturino}

1901 Diccionario en lengua tarasca o de Michoacán, Antonio Peñafiel (ed.), Palacio Nacional, México.

1997 Vocabulario en lengua de Mechuacan, Agustín Jacinto Zavala, Clotilde Martínez y Benedict Warren (eds), El Colegio de Michoacán, Zamora.

\section{Graulich Michel}

1992 "Las brujas en las peregrinaciones aztecas ", Estudios de cultura náhuatl, XXII, pp. 87-98.

1997 "Autóctonos y recién llegados en el pensamiento mesoamericano ", in Aranda A. Garrido (ed.), Pensar América. Cosmovisión mesoamericana y andina, Obra social y cultural Caja Sur, Ayuntamiento de Montilla, Córdova, pp. 139-155.

Greenberg Joseph H.

1987 Language in the Americas, Stanford University Press, Stanford.

\section{HaSKell David}

2008 " The cultural logic of hierarchy in the Tarascan state. History as ideology in the Relación de Michoacán ", Ancient Mesoamerica, 19, pp. 231-241.

Hernández Arana Xajila Francisco y Francisco Kej Díaz Gebuta

1934 Memorial de Tecpan-Atitlan, Antonio Villacorta (ed.), Tipografía nacional, Guatemala.

\section{Hurtado Mendoza Francisco}

1986 La religión prehispánica de los purépechas, Linotipográfica "Omega », Morelia.

\section{KIRCHHOFF Paul}

1956 "La Relación de Michoacán como fuente para la historia de la sociedad y cultura tarascas », Reproducción facsímil del Ms. CIV 5 de El Escorial, José Tudela (ed.), Aguilar, Madrid.

LE CLÉzıo Jean-Marie G.

1988 Le rêve mexicain ou la pensée interrompue, Gallimard, Paris.

\section{LEón Nicolás}

1906 Los tarascos. Notas históricas, étnicas y antropológicas, tercera parte, Imprenta del Museo Nacional, México. 


\section{LÉvi-Strauss Claude}

1955 "The structural study of myth", in Thomas A. Sebeok (ed.), Myth a symposium, Indiana University Press, Bloomington, pp. 81-106.

Leyenda de los soles

ver Códice Chimalpopoca

\section{LIEDTKE Stefen}

2001 "Comparación de léxico tarasco-quechua ", Alma Mater, 20, Universidad Nacional Mayor de San Marcos, Lima, pp. 57-68.

López Austin Alfredo

1976 "El fundamento mágico-religioso del poder », Estudios de cultura náhuatl, 12, pp. 197-240.

1981 Tarascos y mexicas, FCE, SEP, México.

1989 Hombre-Dios. Religión y política en el mundo náhuatl, IIA, UNAM, México.

MARTínez GonzÁlez Roberto

2007 «Nahualli, imagen y representación », Dimensión antropológica, 38, pp. 7-48.

2008 «Dioses propios y ajenos: deidades patronas y realeza sagrada entre los purépechas del siglo XVI ", Revista Española de Antropología Americana, 39 (1), pp. 53-76.

Memorial de Tecpan-Atitlan

ver Hernández

\section{Michelet Dominique}

1989 "Histoire, mythe et apologue: notes de lecture sur la seconde partie de la Relación [...] de Michoacán ", in Dominique Michelet (ed.), Enquêtes sur l'Amérique moyenne: mélanges offerts à Guy Stresser-Péan, Instituto Nacional de Antropología e Historia, Cousejo Nacional para la Cultura y los Artes, Centre d'Études Mexicaines et Centreaméricaines, México, pp. 105-113.

1998 «Reino y reyes tarascos », Arqueología Mexicana, 6 (32), p. 50-57.

Michelet Dominique, Grégory Pereira y Gérald Migeon

2005 «La llegada de los uacúsechas a la región de Zacapu, Michoacán: datos arqueológicos y discusión ", in Linda Manzanilla (ed.), Reacomodos demográficos del Clásico al Posclásico en el centro de México, IIA, UNAM, México, pp. 137-153.

MOHENo Cesar y Ricardo BARTHELEMY

1994 En la nostalgia del futuro: la vida en el bosque indigena de Michoacán, CEMCA, El Colegio de Michoacán, Zamora.

\section{MonZón Cristina}

2005 «Los principales dioses tarascos: un ensayo de análisis etimológico en la cosmovisión tarasca », Relaciones. Estudios de Historia y Sociedad, 104, pp. $135-168$

MOTTE-Florac Elisabeth

1997 «Santos, humores y tiempo: el clima y la salud entre los p’urhépecha de la Sierra Tarasca (Michoacán, México) ", in Marina Goloubinoff, Esther Katz 
y Annamaria Lammel (eds), Antropología del clima en el mundo hispanoamericano, 2 vols, Biblioteca Abya-yala, Quito.

\section{Pollard Perlstein Helen}

1994 «La construcción de ideología en el surgimiento del estado tarasco prehispánico », in Brigitte Boehm (ed.), El Michoacán antiguo, El Colegio de Michoacán, Zamora, pp. 221-249.

Popol Vuh

1971 Munro Edmonson (trad.), Middle American Research Institute, Tulane University, New Orleans.

RamíRez Francisco

1980 "Relación sobre la residencia de Michoacán [Pazcuaro] 》, in Francisco Miranda (ed.), Relación de Michoacán, Fimax Publicistas, Morelia.

REA Alonso de la

1996 Crónica de la orden de N. seráfico P. S. Francisco, Provincia de S. Pedro y S. Pablo de Mechoacan en la Nueva España, Patricia Escandón(ed.), El Colegio de Michoacán, Zamora.

Relación de Michoacán

ver Alcalá

Relaciones geográficas del siglo xVI. Michoacán

1987 René Acuña (ed.), IIA, UNAM, México.

Reyes Rodríguez Andrés et al.

1982 Mitos de la Meseta tarasca, un análisis estructural, UNAM, Universidad Autónoma de Aguascalientes, Aguascalientes.

\section{Ruiz Eduardo}

1979 Michoacán. Paisajes, tradiciones y leyendas, Editorial Innovación, México.

SAHAGún Bernardino de

1956 Historia general de las cosas de la Nueva España, 4 vols, Angel María Garibay (ed.), Ed. Porrúa, México.

\section{Saldivar Pérez Salvador}

1993 "Tzintzuntzan: tradiciones y leyendas de mi pueblo ", in Aída Castilleja y Victor Valencia (eds), El lago de Pátzcuaro, su gente, su historia y sus fiestas, INAH, SEP, México, pp. 155-179.

Seler Eduard

2000 «Los antiguos habitantes de Michuacan », in Jerónimo de Alcalá, Relación de Michoacán, Moisés Franco Mendoza et al. (eds), El Colegio de Michoacán, Gobierno del Estado de Michoacán, Zamora, pp. 147-233.

\section{SWADESH Mauricio}

1967-1968 «Un nexo prehispánico entre quechua y tarasco », Anales de Antropología, 1, pp. 127-138. 


\section{Título de Totonicapán}

1983 Robert M. Carmack y James L. Mondloch (eds), IIF, CEM, UNAM, México.

\section{Título de Pedro Velasco}

1989 in El Titulo de Yax y otros documentos quichés de Totonicapan, Guatemala, Robert M. Carmack y James L. Mondloch (eds), UNAM, México, pp. 139-192.

Título de Yax

1989 in El Título de Yax y otros ducumentos quichés de Totonicapan Guatemala, Robert Carmack y James Mondloch (eds), UNAM, México, pp. 33-129.

\section{VelásQuez Gallardo Pablo}

1978 Diccionario de lengua phorhepecha, FCE, México.

2000 La hechicería en Charapán, Michoacán, Universidad Michoacana de San Nicolás de Hidalgo, Morelia.

\section{ZANTwIJK Rudolf A. M. van}

1974 Los servidores de los santos. La identidad social y cultural de una comunidad tarasca en México, INI, México. 